\title{
Inexperienced Humanitarians? William Wilberforce, William Pitt, and the Execution Crisis of the $1780 \mathrm{~s}$
}

\author{
SIMON DEVEREAUX
}

For most historians, William Wilberforce is not immediately associated with the history of capital punishment, at least not beyond his occasional efforts to solicit mercy for individuals sentenced to death, and his distinctly subaltern role in the decisive early nineteenth century parliamentary debates over the abolition of the death penalty in England. ${ }^{1}$ Most scholars concern themselves with the first of the two "great objects" of which, in a diary entry for October 28, 1787, Wilberforce declared that "God Almighty has set before me ... the suppression of the slave trade and

1. Leon Radzinowicz, History of English Criminal Law and Its Administration from 1750, 5 vols. (London: Stevens \& Sons, 1948-68), I, chs 15-16; Randall McGowen, "The Image of Justice and Reform of the Criminal Law in Early Nineteenth-Century England," Buffalo Law Review 32 (1983): 89-125; and Richard R. Follett, Evangelicalism, Penal Theory and the Politics of Law Reform in England, 1808-30 (Basingstoke: Palgrave Macmillan, 2001), 91-99, 147-60.

Simon Devereaux is Associate Professor of History at the University of Victoria, Canada $<$ devereau@uvic.ca>. The earliest version of this article was prepared for the "Religion, Social Conscience, and the Global Age" seminar at the School of American Research (Santa Fe, NM) in January 2007. Devereaux is grateful to Nicholas Rogers for inviting him to participate, to James F. Brooks and Susan Foote for their generosity during the meeting, and to his fellow participants for their many helpful comments. He also acknowledges the feedback and encouragement he received when the article was presented to the Early Modern Research Collective at the University of Victoria. And he thanks John Beattie, Peter King, and Andrea McKenzie for their close and critical readings of a later version; Richard Ward, not only for reading the article but also for allowing him to read and to cite Ward's own unpublished work while revising it; and the anonymous readers for this journal, who helped the final version come to light. 
the reformation of manners." 2 That concern is easily justified: the abolition of the slave trade quickly became the central preoccupation of Wilberforce's public life, and its implications were of global significance. ${ }^{3}$ His second professed mission of 1787 onwards - to help launch and sustain the Society for Giving Effect to His Majesty's Proclamation against Vice and Immorality - has inspired a smaller, although no less rich, body of scholarship. ${ }^{4}$ Our broad perspective on Wilberforce's public life remains that which was first laid down half a century ago, and which has subsequently been reinforced by historians of gender such as Leonore Davidoff and Catherine Hall. Wilberforce and his associates are principally seen as the progenitors of nineteenth century moral earnestness and spiritual idealism, as well as the feminine ideal of "the Angel in the House." They were, as Ford K. Brown suggested in 1961, the "Fathers of the Victorians."

In fact, capital punishment greatly concerned Wilberforce during the earliest phases of his public career. This article explores the immediate contexts of two of his earliest public efforts: his failed and largely forgotten "Felons Anatomy" bill of 1786; and his cofounding of the Proclamation Society the year afterwards. ${ }^{6}$ The first of these two proposals, which sought to impose the extraordinary stigma of postmortem dissection upon executed felons, puzzled at least one of Wilberforce's biographers, John Pollock, who attributed this "somewhat bizarre measure" to "Wilberforce's inexperience as a humanitarian". ${ }^{7}$ It might also seem strange to those historians

2. Robert Isaac Wilberforce, and Samuel Wilberforce, The Life of William Wilberforce, 5 vols. (London: John Murray, 1838), I:149.

3. Sir Reginald Coupland, Wilberforce (Oxford: Clarendon Press, 1923; revised ed., 1945); Robin Furneaux, William Wilberforce (London: Hamish Hamilton, 1974); John Pollock, Wilberforce (London: Constable, 1977); and William Hague, William Wilberforce: The Life of the Great Anti-Slave Campaigner (London: HarperPress, 2007).

4. Donna T. Andrew, Philanthropy and Police: London Charity in the Eighteenth Century (Princeton: Princeton University Press, 1989), ch 6; M.J.D Roberts, Making English Morals: Voluntary Associations and Moral Reform in England, 1787-1886 (Cambridge: Cambridge University Press, 2004), chs 1-2; and Joanna Innes, "Politics and Morals: The Reformation of Manners Movement in Later Eighteenth-Century England," in Inferior Politics: Social Problems and Social Policies in Eighteenth-Century Britain (Oxford: Oxford University Press, 2009), 179-226.

5. Maurice T. Quinlan, Victorian Prelude: A History of English Manners, 1700-1830 (New York: Columbia University Press, 1941); Ford K. Brown, Fathers of the Victorians: The Age of Wilberforce (Cambridge: Cambridge University Press, 1961); and Leonore Davidoff and Catherine Hall, Family Fortunes: Men and Women of the English Middle Class, 1780-1850 (London: Hutchinson, 1987), pt 1.

6. In so doing, I am expanding upon the brief account provided in Follett, Evangelicalism, Penal Theory and Law Reform, 92-94.

7. Pollock, Wilberforce, 40-42. 
who see this era as being distinguished by the emergence of a powerfully humanitarian, self-consciously "sympathetic" mindset among England's propertied elites: a mindset of which Wilberforce has generally been taken to have been a principal advocate and architect. ${ }^{8}$ Such historians have argued that a more and more "feeling" attitude toward the sufferings endured by various classes of humanity - not only of slaves overseas, but of convicted criminals at home - made the use of capital punishment less and less acceptable, as well as providing a coherent rationale for that growing use of imprisonment that characterized late Hanoverian England. ${ }^{9}$ Such views have been powerfully challenged by V.A.C. Gatrell in The Hanging Tree, a celebrated and wide-ranging study of the culture and workings of capital punishment in early nineteenth century England. Gatrell argues that such pressures as were exerted to save the lives of condemned criminals by Wilberforce and other ostentatiously "humanitarian" sorts were both socially selective (they usually only championed prisoners whose social-economic status and professed mentalities were akin to their own) and far too small-scale and intermittent to make anything but the tiniest dent in the vast number of people who were being hanged during the last years of "the Bloody Code." 10

The following analysis presents evidence both to support and to qualify both perspectives. ${ }^{11}$ By comparison with Gatrell, it will be argued here,

8. Paul Langford, A Polite and Commercial People: England, 1727-1783 (Oxford: Clarendon Press, 1989), ch. 10; and G.J. Barker-Benfield, The Culture of Sensibility: Sex and Society in Eighteenth-Century Britain (Chicago: University of Chicago Press, 1992). Studies that explore some of the more ambiguous dimensions of the "humanitarian" movement include: Randall McGowen, "Power and Humanity, or Foucault Among the Historians," in Reassessing Foucault: Power, Medicine and the Body, eds. Colin Jones, and Roy Porter (London: Routledge, 1994), 91-112; Karen Halttunen, "Humanitarianism and the Pornography of Pain in Anglo-American Culture," American Historical Review 100 (1995): 303-34; and Randall McGowen, "Cruel Inflictions and the Claims of Humanity in Early Nineteenth-Century England," in Assaulting the Past: Violence and Civilization in Historical Context, ed. Katherine D. Watson (Newcastle: Cambridge Scholars Press, 2007), 38-57. For a more thoroughly alternative reading of the era, see Simon Dickie, Cruelty and Laughter: Forgotten Comic Literature and the Unsentimental Eighteenth Century (Chicago: University of Chicago Press, 2012).

9. Randall McGowen, "A Powerful Sympathy: Terror, the Prison, and Humanitarian Reform in Early Nineteenth-Century Britain," Journal of British Studies 25 (1986): 312-34; McGowen, "The Body and Punishment in Eighteenth-Century England," Journal of Modern History 59 (1987): 651-79; and Dana Y. Rabin, Identity, Crime, and Legal Responsibility in Eighteenth-Century England (Basingstoke: Palgrave Macmillan, 2004).

10. V.A.C. Gatrell, The Hanging Tree: Execution and the English People, 1770-1868 (Oxford: Oxford University Press, 1994), esp. pt. III-IV.

11. Two sustained critical responses to Gatrell are Sara Sun Beale, and Paul H. Haagen, "Revenge for the Condemned," Michigan Law Review 94 (1995-96): 1622-59; and Randall 
first, that in London at least, far more people were being hanged during the 1780 s than during the post-Napoleonic era. Second, and in contrast to Gatrell's portrait of an unremittingly severe-minded ruling elite, ready and willing to enforce "the Bloody Code" until the eve of its abolition in the 1830 s, this article will demonstrate that, as early as the 1780 s, some of the nation's leading statesmen - particularly the prime minister, William Pitt the Younger - actively sought practical alternatives to an overly extensive use of the gallows. ${ }^{12}$ To historians who see the 1780 s as an era of rising sympathetic and humanitarian sentiments, however, this article also presents a qualifying perspective. Although younger statesman such as Pitt and his friend Wilberforce wanted to reduce that intensive use of the gallows which characterized this first decade of their public lives, they were also obliged to contend with powerful arguments in favor of a policy of maximum severity. That policy, substantively driven and sustained by an "older" generation of political and legal officials, could nevertheless be persuasively rationalized in the immediate context of the times. England experienced a crime wave of unprecedented scale and persistence following the end of the war with America; and until almost the end of the decade, Pitt's government repeatedly failed to find effective alternatives, in the realms of punishment and policing alike, to such a heavy a reliance on the gallows.

This persistent crisis of criminality and execution levels provided the common and compelling - but also temporally specific - impetus to both Wilberforce's "Felons Anatomy bill" of 1786 and his adoption of the Proclamation Society the year after. Both measures were intended to serve other urgently felt public purposes as well. The particular support that they enjoyed from Pitt's government, however, derived first and foremost from the prospect they afforded of reducing the wide-scale imposition of capital punishment. They were meant to serve a basic and (for some, but only some) urgently felt humanitarian aim of the moment: to find a means whereby the large numbers of people being sent to the gallows might permanently be reduced to levels that were more in accord with a growing body of moral and intellectual objections to capital punishment from the mid-eighteenth century onwards. As such, they essentially reflected the committed public humanitarian whom Wilberforce was in the process of becoming. Close analysis of these two measures and their immediate

McGowen, "Revisiting The Hanging Tree: Gatrell on Emotion and History," British Journal of Criminology 40 (2000): 1-13.

12. For a more sustained argument on these points, see Simon Devereaux, "England's 'Bloody Code' in Crisis and Transition: Executions at the Old Bailey, 17601837,"Journal of the Canadian Historical Association 24 (2013): 71-113. 
contexts sheds light on some of the more unusual, unexpected, and (sometimes) seemingly contradictory dimensions of humanely inspired efforts to restrict the use of capital punishment in late eighteenth century England.

\section{Execution, Transportation, and Policing in London, 1782-85}

Both the timing of Wilberforce's two initiatives and the support they enjoyed from Pitt's government stemmed from the comprehensive and transparent failure of that government's established policies on criminal law. Pitt and his home secretary, Lord Sydney, had helped to establish those policies during the short-lived ministry of the Earl of Shelburne (July 1782-February 1783), in which Pitt had served as chancellor of the exchequer and Sydney had (again) been home secretary. ${ }^{13}$ The question of how best to deal with the rising tide of convicted criminality was an unusually urgent one in the years immediately following the end of the war with America. Recurrent experience over the previous century had demonstrated that crime levels seemed to increase dramatically during the severe social-economic dislocations that followed the end of war. Whether or not that was truly the case (some historians have doubts), convictions for crime certainly surged after each war ended. ${ }^{14}$ By the early 1780 s, however, the only widely accepted secondary punishment for prisoners convicted of capital crimes, transportation to the American colonies, had been in

13. Sydney was then still a commoner, Thomas Townshend. He was created 1st Baron Sydney soon after Shelburne fell from office, and was promoted to Viscount on his final departure from Pitt's government in June 1789. See Oxford Dictionary of National Biography (Townshend, Thomas, 1st Vt Sydney, 1733-1800); and Sir Lewis Namier, and John Brooke, eds., The History of Parliament: The House of Commons, 1754-1790, 3 vols. (London: Secker \& Warburg, 1964), III:554-56. After a long interval, Lord Shelburne has attracted renewed interest among historians; in addition to John Norris, Shelburne and Reform (London: Macmillan, 1963), and Charles Stuart, "Lord Shelburne," in History and Imagination: Essays in Honour of H.R. Trevor-Roper, eds. Hugh LloydJones, Valerie Pearl, and Blair Worden (London: Gerald Duckworth, 1981), 243-53, see now Nigel Aston, and Clarissa Campbell Orr, eds., An Enlightenment Statesman in Whig Britain: Lord Shelburne in Context, 1737-1805 (Woodbridge: The Boydell Press, 2011).

14. Douglas Hay, "War, Dearth and Theft in the Eighteenth Century: The Record of the English Courts," Past \& Present 95 (1982): 117-60; J.M. Beattie, Crime and the Courts in England, 1660-1800 (Princeton: Princeton University Press, 1986), chs. 3-5; V.A.C. Gatrell, "Crime, Authority and the Policeman-State," in The Cambridge Social History of Britain, 1750-1950, 3 vols., ed. F.M.L. Thompson (Cambridge: Cambridge University Press, 1990), III:243-310; Peter King, Crime, Justice, and Discretion in England, 17401820 (Oxford: Oxford University Press, 2000), pt. 2; and Nicholas Rogers, Mayhem: Post-War Crime and Violence in Britain, 1748-53 (New Haven: Yale University Press, 2012). 
abeyance since the outbreak of war in 1775. Imprisonment at hard labor on board prison hulks moored in the river Thames, implemented in 1776, had soon proven to be a controversial and generally unacceptable alternative: so much so that, even though the Penitentiary Act of 1779 promised the construction of a pair of buildings in which the secure and appropriately disciplined confinement of prisoners might at last be achieved on an extensive scale, it could not be passed through parliament without also promising the resumption of transportation for much the same categories of convicts as had been subject to transportation before $1775 . .^{15}$

Such enthusiasm as had once prevailed for the penitentiary project, in government circles at any rate, was ebbing by the end of the war. The general anxiety over the state of public finance that dominated parliamentary politics from the 1780s onwards severely curbed any appetite for a controversial penal experiment as expensive as the penitentiaries promised to become. ${ }^{16}$ The project's supervisors estimated the minimum cost for constructing the two buildings proposed under the Penitentiary Act to be almost $£ 150,000$, a sum that comprised nearly $60 \%$ of all nonmilitary expenditure (outside the Civil List) for $1782 .{ }^{17}$ At the end of September 1782, Shelburne's government informed the project's supervisors "that new measures were about to be taken with respect to felons, which made the hastening the Penitentiary Houses less necessary," a statement that proved to be a politely muted prelude to a refusal to make any further funds available. ${ }^{18}$ The most direct pressure on government to persist with a national penitentiary scheme was further reduced when the project's two most active proponents, Sir Charles Bunbury and Sir Gilbert Elliott, both lost their seats in the general election of $1784 .{ }^{19}$

Shelburne's government now gave priority to the two most important punishments that had long since been imposed upon the most serious

15. 19 Geo. III, c.74. For context, see Beattie, Crime and the Courts, 538-82; Simon Devereaux, "The Making of the Penitentiary Act, 1775-1779," Historical Journal 42 (1999): 405-33; and King, Crime, Justice, and Discretion, 263-70.

16. Philip Harling, The Waning of 'Old Corruption': The Politics of Economical Reform in Britain, 1779-1846 (Oxford: Clarendon Press, 1996); and Earl A. Reitan, Politics, Finance, and the People: Economical Reform in England in the Age of the American Revolution, 1770-92 (Basingstoke: Palgrave Macmillan, 2007).

17. Commons Journals 39 (1782-84): 1042-43; and B.R. Mitchell, and Phyllis Deane, Abstract of British Historical Statistics (Cambridge: Cambridge University Press, 1971), 391.

18. Commons Journals 39 (1782-4): 1041.

19. Namier and Brooke, eds., History of Parliament, II:136-40, 394-96. Both would be re-elected a few years later-Elliott in 1786, Bunbury in 1790 - after which Bunbury in particular would resume his efforts on behalf of the penitentiary project. See R.G. Thorne, ed., The History of Parliament: The House of Commons, 1790-1820, 5 vols. (London: Secker \& Warburg, 1986), III:300-301, 693-96. 
criminal offenders: execution and transportation overseas. In the same month that the penitentiary project was effectively cancelled, and in light of "the great number of robberies that have been lately committed, and attended with acts of great cruelty," the government resolved (at least in London) "to grant no pardon or respite to any person convicted of such offenses, on any solicitation whatsoever." 20 At the same time, the active search began for an appropriate new destination with which the full-scale transportation of Britain's convicts might be resumed. ${ }^{21}$ Disillusion with the experience of the hulks had reinforced the preference of many officials, especially in metropolitan London, for sending the worst classes of convicts (next to those who were actually hanged) overseas. ${ }^{22}$ From the early 1770 s at least, Africa had been suggested as a more imposing destination than an America whose explosive social-economic growth over the course of the century had rendered it far too hospitable for transportation there to seem an appropriately severe fate for serious criminals. ${ }^{23}$

Shelburne's government probably expected the unswerving imposition of executions to be only a temporary necessity. The principal strategy for reducing crime was to emphasize prevention in the first instance rather than any hope of reforming criminals through more effective modes of secondary punishment. "I was assured," Shelburne later wrote, in recalling the cancellation of the penitentiary project, "that if the number of ale-houses could be lessened, the Vagrant Act enforced, and the general administration of justice as it stood invigorated, a great deal might be done without

20. Annual Register 25 (1782): 220; and Morning Chronicle, September 13, 1782 . The focus upon robbery, as will be explained, would soon prove to be somewhat misguided.

21. William L. Clements Library, University of Michigan (Ann Arbor), Shelburne Papers $152 / 40$.

22. For examples of such remarks between the mid-1770s and the late 1780 s, see: Joseph Redington, and Richard Arthur Roberts, eds., Calendar of Home Office Papers of the Reign of George III, 1760-1775, 4 vols. (London: Her Majesty's Stationery Office, 1878-99), IV:11; British Library, Add[itional] MS 34413 (Auckland Papers), ff. 20-21; The National Archives (UK; hereafter "NA"), HO 42/3 f.221; Gentleman's Magazine 56 (1786): 168, 264; John Stockdale, ed., The Debates and Proceedings of the House of Commons and Lords, 21 vols. (London, 1784-92), VII:366; XX:195; and John Debrett, ed., The Parliamentary Register; or, History of the Proceedings and Debates of the House of Commons and the House of Lords, 45 vols. (London, 1780-96), XXVIII:326-27.

23. William Cobbett, ed., The Parliamentary History of England, from the Earliest Period to the Year 180316 (1765-71): 941-43; and A. Roger Ekirch, Bound for America: The Transportation of British Convicts to the Colonies, 1718-1775 (Oxford: Clarendon Press, 1987), 228-29. For a comprehensive account of the "African interval" in English convict transportation, see Emma Christopher, A Merciless Place: The Lost Story of Britain's Convict Disaster in Africa and How It Led to the Settlement of Australia (Sydney: Allen \& Unwin, 2010). 
having recourse to any new institution." 24 This change in direction was publicly announced in the king's speech at the opening of parliament in December 1782: "It were much to be wished that [theft and robbery] could be prevented in their infancy, by correcting the vices become prevalent in a most alarming degree." 25

This was only the latest recrudescence of a long-established body of thinking as to how best to tackle crime. Throughout the eighteenth century (and long before), it was generally believed that the most effective means of preventing the worst sorts of crimes was to ensure that less serious offenses - petty thieving, drinking, gambling and sexual misconductwere sternly dealt with when first they occurred. This stemmed from the belief that serious criminals were not "born" that way, and that poverty or any other environmental circumstances were neither rational motives nor excuses for criminality. The rise to pre-eminence of those modern perceptions lay almost a century in the future. ${ }^{26}$ Rather, the capacity and inclination for the worst sorts of criminality grew within each individual offender by successive degrees of moral corruption. The boy who pilfered seemingly unimportant items and who grew accustomed to lying to mask his minor failings, if not immediately and unwaveringly corrected both morally and physically, grew into the youth who neglected his studies and other assigned duties, and developed a taste for such lax pursuits as gaming, drinking, and theater going. If still no intervention were made in these adolescent ill-courses, the youth might then became a man with a confirmed taste for those activities via persistent association with "bad company" (reprobate men and women of easy virtue) and would finally turn to robbery and burglary to sustain his corrupt lifestyle. This life's path, once embarked upon, was an ever-steepening downward slope. If not checked at some stage by an appropriately scaled degree of punishment, the boy who erred in only minor ways might become a man who ended his days on the gallows. ${ }^{27}$ So hardened would he have become, in both inclinations and sensibility, that he would pass all points of

24. Memoirs of the Life of Sir Samuel Romilly, 3 vols., 2nd ed. (London: John Murray, 1840), I:328-29.

25. Commons Journals 39 (1782-84): 5.

26. David Garland, Punishment and Welfare: A History of Penal Strategies (Aldershot: Gower, 1985); Leon Radzinowicz, and Roger Hood, A History of English Criminal Law and Its Administration from 1750 - Volume Five: The Emergence of Penal Policy (London: Stevens \& Sons, 1986); Martin J. Wiener, Reconstructing the Criminal: Culture, Law and Policy in England, 1830-1914 (Cambridge: Cambridge University Press, 1990), ch. 4-9; and Lucia Zedner, Women, Crime, and Custody in Victorian England (Oxford: Clarendon Press, 1991), pt. iii.

27. My use of the male pronoun is deliberate; the model characteristically invoked young men rather than women. 
reclamation and become fit for no worldly purpose other than to serve as an imposing example to those who remained redeemable. ${ }^{28}$ The night before he was hanged for forgery in March 1784, John Lee reportedly wrote a letter in which he recalled his youthful susceptibility "not only [to] the follies, but even the vices of my companions" and counselled others against neglect of Christian belief. ${ }^{29}$ Similarly Joseph Mayett, a soldier of the Napoleonic era, recounted an adolescence in which, having "done all that lay in my power to stifle the Convictions of Conscience," he "went from bad to worse until almost everybody that knew me Cried out Shame upon me, for there was hardly any mischief done in the place but I had a hand in." Finally, after a near-escape while stealing in an orchard, Mayett began "to tremble and Resolved to give out thieving, for I thought that though I had escaped Justice that time, if I still practised it would harden me more in it and bring me to the gallows at last, so I gave it up altogether." 30

In a world in which both familial and political authority were still viewed in essentially Christian and patriarchal terms - and therefore as being fundamentally intertwined, and mutually reinforcing - the main responsibility for correcting errant tendencies lay first, among children and adolescents, with parents, masters, and mistresses; and subsequently, among adults, with magistrates. As far back as the late Middle Ages, the regulation of morals offenses had been a concern for royal law. Such concerns were intermittently revitalized in the early modern era, perhaps especially under the pressure of Puritan social reform movements, ${ }^{31}$ and they enjoyed renewed periods of energy (as will be discussed in the last section of this article) in later Stuart and Hanoverian England in the form of "reformation of manners" movements. That a similarly revitalized commitment underpinned the Shelburne government's renunciation of the penitentiary

28. Beattie, Crime and the Courts, 421-23, 494-99, 549-53, 601-5, 624-25, 629; J.M. Beattie, Policing and Punishment in London, 1660-1750: Urban Crime and the Limits of Terror (Oxford: Oxford University Press, 2001), 51-62; Andrea McKenzie, Tyburn's Martyrs: Executions in England, 1675-1775 (London: Hambledon Continuum, 2007), 55-67.

29. Gentleman's Magazine 54 (1784): 226, 304 (quote); George Colman, Random Records, 2 vols. (London: Henry Colburn and Richard Bentley, 1830), II:116-31.

30. Ann Kussmaul, ed., The Autobiography of Joseph Mayett of Quainton, 1783-1839 (Aylesbury: Buckinghamshire Record Society, 1986), 14-15.

31. The secondary literature is enormous. Most recently, see Marjorie Keniston McIntosh, Controlling Misbehavior in England, 1370-1600 (Cambridge: Cambridge University Press, 1998); Steve Hindle, The State and Social Change in Early Modern England, c.1550-1640 (Basingstoke: Macmillan, 2000), ch. 7; Paul Griffiths, Lost Londons: Change, Crime and Control in the Capital City, 1550-1660 (Cambridge: Cambridge University Press, 2007); and Frank Rexroth, Deviance and Power in Late Medieval London (Cambridge: Cambridge University Press, 2007). 
project was clearly suggested, as has already been noted, in the king's speech to parliament in December 1782. It was even more explicitly spelled out in the preliminary draft of that speech:

But as it is to [be] wished that these Crimes [i.e., capital robberies] should be prevented rather than punished, I must earnestly recommend to your Consideration to revise such Laws as have been hitherto Made for the Discountenancing \& suppressing those Vices, by which the Younger Part of the Lower Orders of People are often impelled to become dangerous instead of useful Members of Society: \& likewise to consider of such regulations as may effectively control \& deter those by whose seduction these unhappy People are generally led into habits dangerous to themselves, as well as detrimental to their Fellow Subjects. ${ }^{32}$

This is exactly what Shelburne's home secretary asked London's magistrates to start doing one month after the government had informed the penitentiary's supervisors that their project was now "less necessary."

On October 22, 1782 Thomas Townshend (the future Lord Sydney) sent a letter to the chairmen of the sessions of the peace for the county of Middlesex, the City of London, and St Margaret's Hill (in the county of Surrey). Lamenting "the frequent Robberies and Disorders of late committed in the Streets of London and Westminster," which he attributed to the excessive number of gaming and drinking houses, Townshend ordered the magistrates to convene "frequent Petty Sessions ... in their several Parishes" to ensure that "the High Constables and other proper Officers under their Direction" would more regularly and systematically "search for and apprehend Rogues, Vagabonds, idle and disorderly Persons, in order to their being dealt with according to Law; and likewise ... proceed with Rigour against all Persons harbouring such Offenders, as against those who keep ... Night-houses or Cellars, Tippling or common Gaminghouses, or who practice or encourage unlawful Gaming." 33 These were duties with which magistrates, as well as the constables and other officers who served under them, had long been charged by law, and to which they were occasionally enjoined by government to devote greater attention.

Requiring unpaid magistrates to apply their energies to their prescribed tasks was one thing; ensuring that they did so was another, and to this end Townshend added a new requirement. All of "the said Justices in their respective Sessions" were now requested "to draw up in writing, from Time to Time, an Account of their Proceedings" and to transmit it to the home secretary for communication to the king, so that exemplary justices might

32. NA, SP 37/15, f. 381.

33. London Gazette, October 22-26, 1782. 
be singled out and rewarded for their attention to their duties. ${ }^{34}$ For the first time, government was attempting to apply a substantive "carrot" to an otherwise traditional-looking directive to local officials. ${ }^{35}$ Resolutions were quickly passed in various sessional divisions of the metropolis, but there is little evidence to suggest that this brief flurry of magisterial enthusiasm was sustained much beyond the spring of 1783, when the chair of the Middlesex sessions transmitted an impressively detailed list of proceedings conducted by the rotation office in Whitechapel. ${ }^{36}$

The idea of solving this problem by creating a body of salaried magistrates and constables for the metropolis - men who would, for the first time, be paid to perform the duties required of them-seems to have arisen as early as the spring of 1782, when David Wilmot, the industrious Middlesex JP in charge of the Shoreditch rotation office, submitted such a proposal for the City of Westminster and the County of Middlesex. ${ }^{37}$ Three years later, a bill to that effect was in preparation under the authorship of lawyer John Reeves. A draft was ready by April 11, 1785, and word of the measure began to spread soon after. ${ }^{38}$ Reeve's scheme moved far beyond Wilmot's original proposal, embracing not only Westminster and its suburbs (although not, as had Wilmot's, the rest of the county of Middlesex), but also the adjacent Cities of London (to the east) and Southwark (south of the river), as well as their suburbs.

The scope of the "Metropolitan Police Bill" that was finally introduced in the House of Commons on June 23, 1785, the furore with which it was greeted, and its withdrawal only six days later, have all been extensively studied by historians of English policing. ${ }^{39}$ The ambitions of the measure

34. Ibid.

35. Compare, for example, the otherwise broadly similar injunctions from government of July 1722 (NA, SP 44/122, p.111).

36. London Metropolitan Archives, MJ/OC/10a, pp. 483-87, 490; NA, HO 42/1, f. 345; Morning Chronicle, November 13 1782; and NA, HO 42/2, ff. 98-101.

37. Three copies of Wilmot's scheme exist; they are all undated, but two of them are located so as to suggest their composition during Lord Shelburne's home secretaryship (March-July 1782). See Clements Library, Shelburne Papers 152/45; NA, HO $35 / 5$ (undated "PLAN for establishing a certain number of offices in Westminster and Middlesex under the auspices of Government ....”); and NA, HO 42/1, ff. 431-32. For Wilmot's career as a JP, see Norma Landau, "Gauging Crime in Late Eighteenth-Century London," Social History 35 (2010): 412-17.

38. NA, HO 42/6, f. 183; Morning Chronicle, April 18, 1785.

39. Radzinowicz, History, III:108-21; David Philips, "'A New Engine of Power and Authority': The Institutionalization of Law-Enforcement in England," in Crime and the Law: The Social History of Crime in Western Europe since 1500, eds. V.A.C. Gatrell, Bruce Lenman, and Geoffrey Parker (London: Europa, 1980), 155-89; Ruth Paley, "The Middlesex Justices Act of 1792: Its Origins and Effects" ( $\mathrm{PhD}$ diss., University of Reading, 1983), ch. 6; Elaine A. Reynolds, Before the Bobbies: The Night Watch and 
that was finally presented were remarkable for its time. It proposed to expand the very definitions of policing activity in the metropolis, including regular street patrols of a sort that would ultimately be central to Robert Peel's Metropolitan Police Act of 1829; it also sought to wrest control over all of this much-enhanced activity away from traditional local authorities and to place it more firmly in the hands of the central government. As radical as all this was, however, it should nonetheless be remembered that the core impetus to the bill in the first place had been the government's particular desire to enhance the pursuit, prosecution, and punishment of noncapital crimes as a means to prevent the individual offender's descent into more serious criminality. ${ }^{40}$ The Solicitor General, Archibald Macdonald, suggested as much in his remarks on presenting the bill to the Commons, in which he spoke of how "young children were initiated by the elder rogues, ... and at length these wretches terminated their existence under the hands of the hangman, at 17 or 18 [years of age], though old and accomplished in the mysteries of their profession ....". ${ }^{41}$ In this respect, the 1785 Police Bill was as much an expression of an older notion of preventative policing as of the more modern notion of preventing all crimes via a system of sustained patrolling and surveillance.

Equally importantly, Macdonald's opening remarks emphasized that this radically altered police force would ultimately provide the means by which to reduce an execution rate in London that had now reached horrifying new levels. The impact of the government's September 1782 policy of hanging, without exception, those convicted of "robberies ... attended with acts of great cruelty" is readily apparent in Figure $1 .{ }^{42}$ From 1760 to 1782 , and with the exception of a few marked reversals, the proportion of people convicted of capital crimes at the Old Bailey who were actually executed appears to have been gradually declining. ${ }^{43}$ These were years in which, as

Police Reform in Metropolitan London, 1720-1830 (Basingtoke: Macmillan, 1998), 73-76; and J.M. Beattie, The First English Detectives: The Bow Street Runners and the Policing of London, 1750-1840 (Oxford: Oxford University Press, 2012), 147-59.

40. Many of these changes are apparent in the contrast between the version of the bill preserved in the Parliamentary Archives (The Parliamentary Archives MS 84), which appears to be the copy, with "marginal Abstracts," that Reeves had sent to Lord Chancellor Thurlow in early April 1785 (NA, HO 42/6, f. 183), and the text that was finally submitted to the Commons two and a half months later (Sheila Lambert [ed], House of Commons Sessional Papers of the Eighteenth Century, 145 vols. [Wilmington, DE: Scholarly Resources, 1975], XLVI:503-34).

41. Cobbett, Parliamentary History 25 (1785-86): 888-89 (see also 892-93).

42. Figure 1 excludes people convicted of murder, who were almost invariably hanged, and whose inclusion here might somewhat distort the more precise measurement of shifting government policies on execution and pardon.

43. An attentive reader of Figure 1 will notice, however, that although the proportion of people hanged in London was falling more or less steadily between 1760 and 1782, the 


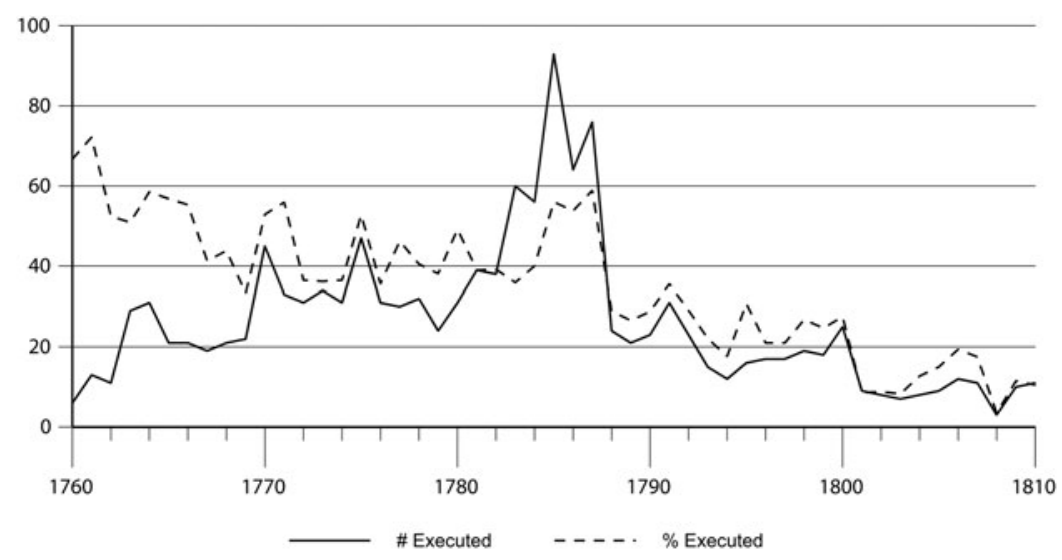

Figure 1. Old Bailey executions, 1760-1810. Source: Execution and Pardon: Capital Convictions at the Old Bailey, 1730-1837. http:/hcmc.uvic.ca/.

Randall McGowen and others have shown, the underlying intellectual and moral bases of capital punishment were being fundamentally challenged. ${ }^{44}$ Between 1782 and 1787, however, there was a marked reversal in this apparent trend toward a reduced use of the gallows. Both the proportion of capital convicts put to death, and especially the absolute number of them, increased rapidly and dramatically. ${ }^{45}$ By 1784 , London newspapers were frequently lamenting both the scale of executions outside Newgate and the ineffective system of policing that apparently made them necessary. ${ }^{46}$

actual number of people being hanged was generally increasing. For a fuller analysis of the "rate" of execution versus the actual "number" executed, see Devereaux, "England's 'Bloody Code' in Crisis and Transition," 82-83.

44. Radzinowicz, History, I:268-86, 301-13; Beattie, Crime and the Courts, 554-59; McGowen, "Body and Punishment," 651-79; McGowen, "'He Beareth Not the Sword in Vain': Religion and the Criminal Law in Eighteenth-Century England," EighteenthCentury Studies 21 (1987-88): 192-211; and McGowen, "The Changing Face of God's Justice: The Debate over Divine and Human Punishment in Eighteenth-Century England," Criminal Justice History 9 (1988): 63-98.

45. Douglas Hay, "The Laws of God and the Laws of Man: Lord George Gordon and the Death Penalty," in Protest and Survival: The Historical Experience: Essays for E.P. Thompson, eds. John Rule, and Robert Malcolmson (London: Merlin Press, 1993), 6163; and Devereaux, "England's 'Bloody Code' in Crisis and Transition," 82-86. Much the same was true on the assizes circuits as well (Beattie, Crime and the Courts, 582-86; and King, Crime, Justice, and Discretion, 273-78).

46. The Times, January 31,1785 , and May 13, 1785. Such comments would only intensify in the years to come. 
Pitt's government was not indifferent to such protests. In introducing the Police Bill, the solicitor general lamented "the crowds that every two or three months fell a sacrifice to the justice of their country, with whose weight, as he said, the gallows groaned; and yet the example was found ineffectual, for the evil was increasing." This was a remarkable confession from one of the government's senior legal officials: a recognition that largescale executions were obviously "ineffectual" as a deterrent; "that the present laws, and the mode of executing them now in use, were inadequate to" the reduction of crime in London; and "that extreme severity, instead of operating as a prevention to crimes, rather tended to inflame and promote them, by adding desperation to villainy." Given "that severity would be ineffectual," the only alternative was "to render detection certain and punishment, with a moderate degree of severity, unavoidable." This fundamental policing task "would never be adequately and effectually performed, unless those to whom the performance was committed, were paid for their trouble" - that is, the hard-pressed magistrates of the metropolis. In this respect, the bill aimed not at "subverting the established system" of magisterial authority in London, but rather sought "to strengthen and support it." 47

He might further have added that some such measure was now made doubly necessary because the principal alternative to hanging - transportation overseas - had not only remained unavailable on a scale large enough to meet the need for far longer than anyone had anticipated in September 1782 , but also now appeared as though it would remain so longer still. Only three months before the Police Bill was introduced, the government's plans to establish a self-sustaining African convict settlement on the island of Lemaine in the river Gambia had seemed to be nearing completion. Then protests had erupted on the floor of the House of Commons, with members of the opposition seriously questioning both the morality and the practical effects of such a scheme. ${ }^{48}$ In addition to disrupting valuable trading concerns in the region (no small consideration in itself, as two subsequent parliamentary committee reports made clear), the conditions in that part of the world were believed to be so harsh as to constitute an effective death sentence. As such, they violated both the spirit and the letter of the laws that prescribed transportation, not only as the main condition of pardon from sentence of death, but also (and perhaps especially) as a sentence in the first instance for less serious, noncapital crimes. ${ }^{49}$ The portrait of

47. Cobbett, Parliamentary History 25 (1785-86): 888-89, 899.

48. Ibid., 391-92, 430-32; and F.P. Lock, Edmund Burke - Volume II: 1784-1797 (Oxford: Clarendon Press, 2006), 21-29.

49. The two subsequent reports of the committee are in Commons Journals 40 (1784-85): 954-60, 1161-64. For the Lemaine scheme and reactions to it, see Alan Atkinson, The 
Lemaine, painted in one newspaper account of the time, was unpromising in the extreme: "[T]he heat in the months of July and August is very great; and towards the equinox, they experience dreadful storms of thunder and lighting. The country on each side [of] the river is peopled by warlike negro nations, who sacrifice to their idol deities such white men as fall into their hands, and whose bodies they devour; which will prevent [the convicts] deserting from the place allotted for them." 50

Some people thought that such conditions perfectly acceptable where the worst sorts of offenders were concerned. "To transport capital felons to Africa, who have received his Majesty's pardon is undoubtedly just," The Times observed. On the other hand, "as it has ever been held a point of law that the order cannot increase punishments, sending persons convicted of [non-capital] larcenies to Africa, which is one high road to eternity, does not appear as consistent with the principles of the British constitution." 51

The ensuing parliamentary committee produced its second and final report on July 28,1785 , recommending a more southerly, coastal region of Africa - Das Voltas - as a more promising site for a permanent, healthy, and affordable convict settlement: the only African site capable of such "Commercial and Political Benefits" as "may be deemed of sufficient Consequence to warrant the Expense inseparable from such an Undertaking," while "at the same Time" restoring "Energy to the execution of the Law, and contribut[ing] to the interior Police of this Kingdom." 52 But Das Voltas had not yet been properly surveyed, so while the government sent out an investigative expedition, the immediate prospects for the resumption of convict transportation were at an end for several months more, and perhaps longer. The almost simultaneous collapse of the government's two principal criminal justice strategies, coupled with persistently high levels of execution, set the stage for William Wilberforce's first major criminal law initiative.

\section{The Felons Anatomy Bill of 1786}

In May 1786, the young Wilberforce- - like Pitt, he was still only twentysix years old - had been an MP for six years. The previous winter, after

Europeans in Australia: A History - Volume One: The Beginning (Melbourne: Oxford University Press, 1997), 52-56; and Christopher, Merciless Place, 301-14.

50. Morning Chronicle, April 15, 1785.

51. The Times, April 13, 1785.

52. Commons Journals 40 (1784-85): 1164. 
several years' enjoyment of the pleasures of London with his hard-drinking friends, he had undergone a religious awakening, one that sounded not unlike the change-of-heart professed by Joseph Mayett. "I must awake to my dangerous state," Wilberforce confided to his diary on Sunday, November 27, 1785, "and never be at rest 'till I have made my peace with God. My heart is so hard, my blindness so great, that I cannot get a due hatred of sin, though I see I am all corrupt, and blinded to the perception of spiritual things." ${ }^{53}$ It seems odd that so newly regenerate a man should have risen in the House of Commons, scarcely half a year later, to propose "a Bill to regulate the Disposal, after Execution, of the Bodies of Criminals condemned and executed for certain heinous Offenses therein to be mentioned." 54

Until recently, Wilberforce's bill had gone almost entirely unnoticed by historians. ${ }^{55}$ It is not noted in Ruth Richardson's celebrated study of the social and cultural background to the Anatomy Act of 1832, nor in any of the more recent accounts of that subject. ${ }^{56}$ It certainly puzzles the one historian of criminal law who has noticed it. ${ }^{57}$ During an era in which most historians are concerned with identifying the early stirrings of humane sentiment and enlightened thought, it seems decidedly peculiar, even perverse, that the leading evangelical of his age should champion so seemingly unfeeling a measure. The bill proposed to make the corpses of certain categories of executed felons more readily available for dissection by students of anatomy, specifically rapists, arsonists, burglars and (a nod here to the government's policy of September 1782) robbers when "the offence was accompanied with wounding, beating or other circumstances of amorality." 58 In other words, it sought to expand upon the Murder Act of 1752 (25 Geo. II, c. 37), which had made the bodies of all

53. Wilberforce and Wilberforce, eds. Life of Wilberforce, I:89-90; quoted in Furneaux, William Wilberforce, 36.

54. Commons Journals 41 (1786): 815.

55. The first full-scale study is Richard Ward, "The Criminal Corpse, Anatomists, and the Criminal Law: Parliamentary Attempts to Extend the Dissection of Offenders in Late Eighteenth-Century England," Journal of British Studies 54 (2015): 63-87. I am grateful to Dr Ward for allowing me to read his article in advance of its publication.

56. Ruth Richardson, Death, Dissection and the Destitute (Chicago: University of Chicago Press, 1987; 2nd ed., 2000); Wendy Moore, The Knife Man (London: Bantam Press, 2005); Helen MacDonald, Human Remains: Dissection and Its Histories (New Haven: Yale University Press, 2006); Druin Burch, Digging Up the Dead: The Life and Times of Astley Cooper, an Extraordinary Surgeon (London: Chatto \& Windus, 2007); and Lisa Rosner, The Anatomy Murders (Philadelphia: University of Pennsylvania Press, 2009).

57. Radzinowicz, History, I: 476-79.

58. Parliamentary Archives, $\mathrm{HL} / \mathrm{PO} / \mathrm{JO} / 10 / 2 / 61$. Richard Ward generously provided me with a copy of the text of the bill, which I was unable to locate myself during a visit to the Parliamentary Archives in January 2002. 
those hanged for that crime available to the surgeons for postmortem dissection. ${ }^{59}$ The mystery of the bill's apparently savage character seems only to be deepened by the subsequent addition to it of a more obviously humane clause, abolishing the burning at the stake of women convicted of treason. ${ }^{60}$ The most detailed modern biography of Wilberforce altogether omits mention of it, perhaps from a sense of the awkwardness or embarrassment it might pose to the great man's reputation. John Pollock concluded that "Wilberforce's inexperience as a humanitarian had muddled him into linking separate causes" in this "somewhat bizarre" measure, echoing Leon Radzinowicz's earlier conclusion that the bill must surely demonstrate that Wilberforce's understanding of "the problem of punishment" was "as yet immature." 61

The Felons Anatomy Bill did have ultimately humane intentions, but we must explore its various contemporary contexts if we are better to grasp the character and extent of that "humanity." Three such contexts need to be considered. First, although the postmortem dissection of convicted criminals was generally regarded with horror by the public at large, the plentiful supply of corpses for anatomical study was ultimately meant to ensure that surgery, an invariably agonizing ordeal in an era before the availability of effective anesthetics, could be performed as swiftly as possible so as to minimize the time in which any patient was kept under the knife. ${ }^{62}$ Second, and although Wilberforce himself by no means concurred in such views, we should at least be aware that the mid-1780s was an era

59. Radzinowicz, History, I:206-9; Peter Linebaugh, "The Tyburn Riot Against the Surgeons," in Albion's Fatal Tree: Crime and Society in Eighteenth-Century England, eds. Douglas Hay, Peter Linebaugh, John G. Rule, E.P. Thompson and Cal Winslow (London: Allen Lane, 1975), 65-117; and Beattie, Crime and the Courts, 78-79, 525-30.

60. It is in this connection that the bill has most often been noticed by legal historians. See Ruth Campbell, "Sentence of Death by Burning for Women," Journal of Legal History 5 (1984): 44-59; Shelley A.M. Gavigan, "Petit Treason in Eighteenth Century England: Women's Inequality Before the Law," Canadian Journal of Women and the Law 3 (1989-90): 335-74; and Simon Devereaux, "The Abolition of the Burning of Women in England Reconsidered," Crime, Histoire et Sociétés 9/2 (2005): 73-98. That this component of the bill of was of purely secondary interest to Wilberforce seems implicit in his failure to reintroduce it as a separate measure during the following two sessions, as well as his apparent failure to take any active role in its ultimate passage in 1790 (Commons Journals 45 [1790]: 454, 460, 498). One of Wilberforce's modern biographers notes only that part of the bill that dealt with the burning of women (Coupland, Wilberforce, 49).

61. Radzinowicz, History, I:477; Furneaux, William Wilberforce, ch. 3; and Pollock, Wilberforce, 40-42.

62. Richardson, Death, Dissection and the Destitute, 41-50; Peter Stanley, For Fear of Pain: British Surgery, 1790-1850 (Amsterdam and New York: Rodopi, 2003), esp. chs. 7-8; and Thomas Dormandy, The Worst of Evils: The Fight Against Pain (New Haven: Yale University Press, 2006), ch. 18. 
in which arguments for maximum severity in the application of the death penalty were advocated - and, for a time, actively put into force - in a number of influential public circles. Third and finally, we need to appreciate that Wilberforce's bill addressed itself to only a specifically defined body of criminal offenders, most notably those convicted of burglary.

\section{The Needs of Anatomists}

The surgical dimension provided the most obvious impetus for the bill. Wilberforce sat in the Commons as one of two MPs for his home county of Yorkshire. One of his close friends there was William Hey, an eminent surgeon in Leeds, who in May 1785 appears to have proposed the idea to both Wilberforce and Walter Stanhope, the Member for Kingston-uponHull. ${ }^{63}$ "Though the knowledge of Anatomy is absolutely necessary to the welfare of mankind," Hey wrote Stanhope, "yet there is in this kingdom no legal provision for the study of it." The result, familiar to readers of Ruth Richardson, was a horrible trade in grave robbing to supply demand, a practice made worse still in that many of the stolen corpses arrived in so desiccated a state as to be dangerously infectious. "These and other considerations," Hey continued, "induce me to think that it would be a proper plan to deliver up the bodies of all executed criminals to the Teachers of Anatomy. Such bodies are the most fit for anatomical investigation, as the subjects generally die in health, the bodies are sound and the parts distinct." Nor should convicted felons expect any better a fate, thought Hey: "Why should not those be made to serve a valuable purpose when dead who were an universal nuisance when living?" Local, provincial interests played an important role as well. Because the Old Bailey conducted trials eight times per year, Hey noted, London surgeons enjoyed reasonably regular access to the fresh corpses of convicted murderers. By comparison, given that trials for felonies in the counties took place only twice a year at the assizes, provincial surgeons were far worse off. In truth, they really only had such access once a year: "The weather is too hot from April to August," Hey maintained, "and all the criminals suffer in this part of the year, except those who are condemned for murder at the Spring Assizes, which usually are held in March." Murderers tried and executed at the summer assizes were likely, after several months' confinement prior to trial, to

63. Namier and Brooke, eds., History of Parliament, III:465-66. In this local connection, it is also significant that Wilberforce's fellow MP for the county, Henry Duncombe, was also one of the three members named by the Commons to prepare a first draft of the bill (Commons Journals 41 [1786]: 815; Namier and Brooke, eds., History of Parliament, II:352-53). 
have become too physically decrepit to provide the surgeons with a useful anatomical subject. ${ }^{64}$

Hey was quite wrong to believe that London benefitted uniquely under the Murder Act of 1752. The need for anatomical subjects was as urgently felt in the capital as elsewhere. Historians of anatomy, from Richardson onwards, have assumed that the Murder Act increased the supply of corpses available to anatomy schools but that the demand for bodies from a rapidly expanding medical profession simply continued to outstrip supply. In fact, although no provision of the Act had specifically stated that anatomization would now be restricted to only the bodies of convicted murders, both the internal logic of the Act - to ensure that a "peculiar mark of infamy may be added to the punishment of death" where murder was concerned (25 Geo II, c. 37, s.1) - and subsequent practice ensured that just such a restriction ensued. After 1752, about eleven more people convicted at the Old Bailey of a crime other than murder were turned over to the surgeons for postmortem dissection. ${ }^{65}$ The number of Old Bailey felons received by the surgeons had averaged five or six per year during the 1730s, a figure that was already considerably lower than the ten bodies per annum that had been promised to London's surgeons since the late seventeenth century. ${ }^{66}$ During the dozen years preceding the Murder Act, the number had already fallen to only one or two per year (and no one at all appears to have been given to the surgeons in 1744-46 and 1749). The yearly averages following passage of the Murder Act in 1752 were certainly an improvement over this: three to four per year for the remainder of the 1750 s, but this fell to only two to three in the 1760s and 1770s, and the six-and-a-half years immediately preceding Wilberforce's bill were positively disastrous for the surgeons. Despite extraordinarily high levels of conviction for other violent crimes at the Old Bailey during the first half of the 1780s, murder convictions yielded an average of only one body per year for the London surgeons. ${ }^{67}$ In short,

64. A.M.W. Stirling, Annals of a Yorkshire House, From the Papers of a Macaroni and His Kindred, 2 vols. (London: John Lane/The Bodley Head, 1911), II:250-1. For the rigors of pretrial confinement in an eighteenth century county gaol, see Beattie, Crime and the Courts, 288-309.

65. The last two were Thomas Ashby and Edward McDonald, jointly convicted of stealing in a dwelling and hanged in October 1773. "[H]aving no friends to bury them," a newspaper reported, "a Surgeon took them, for dissection" (London Chronicle, October 26, 1773).

66. Six were promised to the Royal College of Physicians and four more to the Company of Barber Surgeons (Linebaugh, "Tyburn Riot," 69-78; and Richardson, Death, Dissection and the Destitute, 32-37).

67. Execution and Pardon: Capital Convictions at the Old Bailey, 1730-1837 http:/hcmc. uvic.cal 
far from assuring a permanent and substantial supply of corpses for anatomical study, the practical effect of the Murder Act had been to reduce the available number of bodies far below that which the surgeons had supposedly been assured before 1752, a number that had gone unrevised for almost a century beforehand. ${ }^{68}$

Under these circumstances, it can be no surprise that grave robbing, an activity more famously associated with the early nineteenth century, was already becoming a problem in London by the 1780s, and was therefore one of the impetuses for Wilberforce's Felons Anatomy Bill. In presenting the measure to the Commons, Wilberforce followed Hey in invoking "the extreme difficulty surgeons experience in procuring bodies for dissection, and the shocking custom of digging them up after burial ... frequently in such a state ... that the great end of dissection was foiled," and went on to suggest that "For these reasons, and a variety of others which could be urged, if necessary, [he] presumed there could be no objection to his motion." 69 Grave robbing had recently provoked a scandal in London. In May 1785 a "surgeon of eminence" and the master of a workhouse had been jointly tried at King's Bench for "conspiracy in conveying away dead bodies, for the purpose of dissection." Despite the surgeon's pleas of "the benefits which might accrue to society from the accurate knowledge of anatomy, which could be only thus obtained," each was fined $£ 10 .{ }^{70}$ Another such case would come before the same court only three years later, and the issue would only provoke more and more public outrage until it was ultimately resolved by the Anatomy Act of 1832 (2 \& 3 Will. IV, c.75), which abolished postmortem dissection of convicted murderers, and instead sought to ensure that surgeons would henceforth receive the unclaimed bodies of people who died in the parish workhouse.

But what of the "variety of other" reasons for the bill of which Wilberforce spoke when introducing it? The support that the bill received from government indicates that this was no mere "local" measure, despite the obvious hand of Yorkshire MPs in its initial moving. Henry Dundas,

68. Peter Linebaugh particularly emphasized that the Murder Act was also intended to bring an end to the occasional battles at Tyburn between surgeons seeking to claim the bodies of hanged felons that had been promised them and the families of those felons who viewed their loved ones' postmortem fate with horror ("Tyburn Riot Against the Surgeons," passim). The marked reduction in the provision of felons' bodies to the surgeons in the decade preceding the Murder Act (also implicit in Linebaugh's figure at 77) perhaps indicates that officials were already trying to reduce the number of occasions for such disruptions to the execution ritual.

69. Morning Chronicle, May 17, 1786 (emphasis added).

70. The Times, May 7, 1785 (quote), December 12, 1788; and Kentish Register 2 (1794): 295-99. For late Hanoverian grave robbing and anatomy, see the references in note 56. 
Pitt's right-hand man in the Commons (and a future home secretary), emphasized that the bill would be carefully framed "in order to avoid destroying the effect [that] the sentencing the bodies of malefactors to be anatomized after execution had upon the prejudices of mankind, considered as punishment for crimes." More striking was the reported aid of Pitt himself "in drawing up the motion" for the bill, as well as home secretary Sydney's advocacy of it in the House of Lords following its passage by the Commons. ${ }^{71}$ The hand of government was especially apparent in the withdrawal of the first draft of the bill (presented to the House on June 22) on the grounds of its not having been "properly prepared" and the subsequent presentation of a fully formed substitute the very next day. ${ }^{72}$ This would have been impossibly swift work for a lone MP still new to the processes of legislation. Wilberforce later told Hey that the second version of the bill had been written by the government's law officers and that "one of the most active judges" had consulted "with the rest of the bench at a general meeting" concerning its substance prior to its presentation to the Commons. ${ }^{73}$

Having passed the Commons on July 29, 1786, however, the bill encountered fatal opposition in the Lords from Lord Chief Justice Loughborough. Although primarily offended by the government's omission to consult the judges beforehand (a charge that, as has been mentioned, Wilberforce explicitly denied), Loughborough also objected to the bill's aim of extending the most extreme sentence of English law then available beyond the crime of murder. ${ }^{74}$ Such an alteration, he maintained, would be an "inducement to commit still greater crimes, ... for surely nothing could be more obvious than that, if the same punishment were to attend the convict for burglary as for murder, breaking open a house would generally be attended with murder, as robberies in France were, the criminals there knowing that the commission of the one crime was to receive no greater punishment than the other." Loughborough's views provide a concrete basis for some historians' perceptions of the bill as a regressive measure. However, the home secretary himself specifically refuted any notion that the bill was intended solely to enhance penal severity. Sydney denied "that the object of the Bill was founded in

71. Morning Chronicle, May 17, 1786; and Namier and Brooke, eds., History of Parliament II:354-57.

72. Commons Journals 41 (1786):926, 929-30.

73. Life of Wilberforce, I:114-15.

74. On the principle of consulting the judges, see Douglas Hay, "Hanging and the English Judges: The Judicial Politics of Retention and Abolition," in America's Death Penalty: Between Past and Present, eds. David Garland, Randall McGowen, and Michael Meranze (New York: New York University Press, 2011), 129-65 (esp. 147). 
pure cruelty. This was an imputation so unmerited by the Gentleman who introduced the Bill [i.e., Wilberforce], that he could not suffer it to pass unnoticed. A more worthy, liberal and humane man did not exist; and all who knew him, he was sure, would join with him in declaring, that if any individual was more averse to anything like cruelty than others, that Gentleman was the individual." 75

Wilberforce himself later maintained that Loughborough had known very well what the real purposes of the bill were and that he had opposed it solely for partisan political reasons. ${ }^{76}$ That said, the alacrity with which government abandoned the bill suggests that Loughborough may not have been entirely wrong to perceive the temper of the times as being against any extension, beyond the crime of murder, of the most aggravated mode of execution.

\section{An Age of Maximum Severity}

At the same time, however, other voices were contending loudly for maximum severity, and here we come to a second "humanitarian" intention behind the Felons Anatomy Bill. Even if its aims had been "pure cruelty" so far as those categories of felons to whom it applied were concerned, the bill had nonetheless enjoyed an unproblematic passage through the House of Commons. Rational, sympathetic, and humanitarian critiques of capital punishment had been making some headway during the 1760s and $1770 \mathrm{~s}$. The extraordinary scale of violent crime during the 1780 s, however, prompted others to demand a reversal of this trend. Just a year before Wilberforce's bill, execution without exception for all capitally convicted criminals had been vigorously advocated by Martin Madan in his widelyread Thoughts on Executive Justice (1785). "Methinks," Madan famously remarked, "that our laws are reduced to the state of [toothless] vipers their sting is gone, their fangs are out, their terror is lost; ... the laws shall hurt nobody, who chuses to sport with them." 77 Many disagreed with Madan, but at least one member of the judicial bench seems to have endorsed his reasoning in the starkest possible manner. For the first time in decades - probably more than a century - every capital convict

75. Morning Chronicle, July 6, 1786 (emphasis in original).

76. Life of Wilberforce, I:114-15. Loughborough (the former Alexander Wedderburn) had served as solicitor and then attorney general from 1771 to 1780 ; although now elevated to the second highest judgeship of the realm, until the advent of the French Revolution he was a staunch member of the opposition (Namier and Brooke, eds., History of Parliament, III:618-20).

77. Martin Madan, Thoughts on Executive Justice, with Respect to Our Criminal Laws, Particularly on the Circuits (London: J. Dodsley, 1785), 35-36. 
of the summer assizes for the counties of Essex, Kent and Sussex in 1785 was hanged without exception..$^{78} \mathrm{~A}$ few months later (and only two months before the Felons Anatomy Bill was introduced), the City of London had petitioned government to demand "that the sentence passed on convicts at the Old Bailey, may be fully executed, as a means of deterring those persons now at large, who are continually making depredations on the peaceful inhabitant, from persevering in their mal-practices." ${ }^{\text {79 }}$ City officials could hardly have been taking exception to the execution levels of the previous year. Perhaps they were pushing back against the earliest signs of that relative restraint in the use of the gallows which characterized the year 1786, before the resumption of greater severity the year after (see Figure 1).

Pitt's ministry was thus confronted with a stark dilemma. On the one hand, when introducing the Police Bill in June 1785, it had publicly admitted that large-scale executions were wholly ineffective, and even counterproductive, as a deterrent. On the other, it was obliged to acknowledge strong views, both in the public at large and among the judges themselves, that less restraint, rather than more, was called for in deploying the threat of the gallows. ${ }^{80}$ In attacking the Police Bill, two Aldermen of the City who also sat as MPs had insisted that the unremitting use of capital punishment was the best strategy for reducing crime in London. Benjamin Hammet lamented the prevailing spirit of compassion, which he thought currently prevailed with regard to "thieves and robbers," maintaining that "it was to no purpose to multiply penal laws if they were not put in force." Similar echoes of Martin Madan could be heard in the voice of James Townsend, who insisted that it was "the judge who reprieved enormous offenders, who committed cruelty, and not he who, by dooming such convicts to the fate of the justice of the country and its laws had called down upon them, held out an example of terror to others to avoid meriting a similar punishment." 81 The Felons Anatomy Bill might, therefore, be understood as an effort by Pitt's government to steer a middle path between, on the one hand, a desire to execute fewer criminals, and a determination, on the other hand, to punish those who were to be executed with a more exemplary severity.

78. King, Crime, Justice, and Discretion, 276-77. There are no recommendations for pardon, nor records of any being granted, for those three counties anywhere in the relevant government papers (NA: HO 13/2-3; HO 47/2-3).

79. Morning Chronicle, March 23, 1786.

80. For the varieties of individual judicial severity during this era, see Hay, "Hanging and the English Judges," 136-46.

81. Cobbett, Parliamentary History 25 (1785-6): 902-3, 907-8; and Namier and Brooke, eds., History of Parliament, II:575; III: 537-38. 


\section{The Singular Problem of Burglary}

This leads immediately to the third aspect of the bill, which suggests its ultimately humane intentions: its selectivity as to the categories of offenders to whom it would apply, namely convicted robbers, burglars, arsonists, rapists, and traitors. In practice, however, it would only be applied without exception to robbers whose crimes were "accompanied with wounding, beating or other circumstances of amorality"-in other words, exactly the same sorts of robbers who, in theory, were already routinely refused pardon as a consequence of the government's resolution of September 1782. In the case of the other four classes of offenders, however, each body would only be turned over for anatomization "upon application" from a surgeon. ${ }^{82}$ Three of these four crimes - high treason, rape, and arson-generated far fewer convictions than robbery and burglary. Since 1750, the Old Bailey had produced only fourteen convictions for rape (only six of which actually ended in executions) and only one for arson. Similarly, only one person had been convicted of high treason in the strictest sense of that crime (an overt political betrayal of king and country), although if coining had been intended to be included in that category (as it would be in the strictest interpretation of the law), another fifty-two could be added to the score. ${ }^{83}$ Rape, arson, and treason would have added, at most, on average, only one or two felons' corpses per year for the surgeons from 1750 to 1785 inclusive. In its most frequent operation, the bill was going to apply to selected categories of robbery and burglary, the former specified by the legislation and the latter (apparently) left to the vicissitudes of requests from anatomists.

In practical terms, then, the bill's most striking innovation would have been the public dissection of a substantial proportion of convicted burglars. Loughborough seems clearly to have grasped this particular aim of the bill, referring to how it proposed to apply "the same punishment ... for burglary as for murder." Even more significantly, that focus was emphasized in the home secretary's reply, in which (after having "rescued Mr Wilberforce's character") he argued that, if Loughborough truly insisted that the judges must guide all adjustments to criminal law, he ought then to assist government in framing a new bill "to discriminate the various and distinct crimes

82. Parliamentary Archives, $\mathrm{HL} / \mathrm{PO} / \mathrm{JO} / 10 / 2 / 61$.

83. Execution and Pardon http://hcmc.uvic.ca/. Because coining was deemed to be a form of high treason, those convicted of it were drawn on a sledge to the place of execution (until the abolition of the Tyburn procession in December 1783), and women convicted of the crime were (until 1790) burnt at the stake after being strangled (see the references in note 60). This dimension of the bill perhaps explains why Wilberforce deemed it appropriate to attach to it a proposal to abolish the latter practice, rather than propose a separate measure to that effect. 
classed under the general head of burglary, and to apportion distinct punishments [to them].... He wished ... to have the distinction legally laid down, that the house-breaker, in the worst sense of the word, might not be encouraged in his excess of criminality, from hearing that the offender of the lesser species of guilt, though his crime was classed under the same name as his own, was pardoned." 84

No such bill specifying distinctive categories of burglary ever came forward, but Sydney's professed desire for it suggests the greatest concern that Wilberforce's bill was intended to address: the particular problem of unprecedentedly high levels of conviction for burglary in London and a need to make distinctions among them. When conjoined with Sydney's insistence on Wilberforce's humanitarian motives in sponsoring the measure, as well as the evidence that Pitt's government had taken an active hand in both backing and reshaping it, the real purpose of the Felons Anatomy Bill becomes clear. It was intended to provide a hard-pressed government with a credible strategy for executing fewer burglars without seeming to be "soft" on crime at a time when conviction levels for these worst sorts of capital felonies had reached truly horrific heights. ${ }^{85}$

Figures 2 and 3 demonstrate how remarkably prominent burglary had become by comparison with robbery, the crime that was usually the benchmark of public and official concern about serious criminality in eighteenth century England. ${ }^{86}$ In 1750, a year that saw extraordinarily high levels of conviction for robbery in the crime wave that followed the War of the Austrian Succession (1739-48), only one tenth as many people were convicted of burglary as of robbery. ${ }^{87}$ From the late 1760 s through 1778 ,

84. Morning Chronicle, July 6, 1786 (emphasis in original).

85. This assumes either that the government did not expect that the surgeons would try to claim the body of all burglars, arsonists, rapists, and traitors who were to be hanged for their crimes, or that it did not intend to honor every such request. My sense is that Sydney's call to Loughborough for a means to distinguish among categories of burglary suggests that the government planned to decide for itself which burglars would be deemed suitable for surrender to the anatomists. But in the absence of other documentation, this must remain speculative.

86. For the "image" of robbery - and especially highway robbers - in the eighteenth century, see Gillian Spraggs, Outlaws and Highwaymen: The Cult of the Robber in England from the Middle Ages to the Nineteenth Century (London: Pimlico, 2001); Robert Shoemaker, "The Street Robber and the Gentleman Highwayman: Changing Representations and Perceptions of Robbery in London, 1690-1800," Cultural and Social History 3 (2006): 381-405; and Andrea McKenzie, "The Real Macheath: Social Satire, Appropriation, and Eighteenth-Century Criminal Biography," Huntington Library Quarterly 69 (2006): 581-605.

87. Beattie, Crime and the Courts, 214, 218-22, 226; and Rogers, Mayhem, ch. 2. But for a more sceptical view as to whether indictments and convictions reflected real levels of crime, see King, Crime, Justice, and Discretion, 153-61. Much the same proportions 


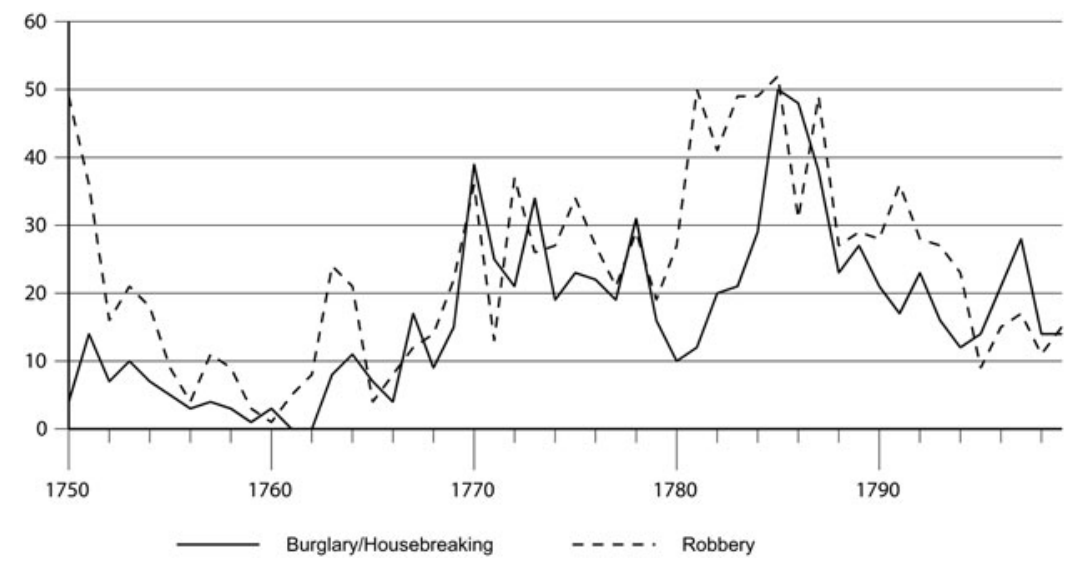

Figure 2. Old Bailey convictions: burglary versus robbery, 1750-99. Source:

Execution and Pardon: Capital Convictions at the Old Bailey, 1730-1837. http:/ homc.uvic.ca/.

however, the conviction rate for burglary suddenly surged from less than half that for robbery to being identical to it. This, as well as the increased numbers of executions that followed (see Figure 1), helps to explain why those two decades witnessed the first widespread expressions of doubt regarding the efficacy of hanging, as well as transportation, as deterrent punishments. Such reservations were apparent in such major publications at the time as the fourth and final volume of William Blackstone's Commentaries on the Laws of England (1769) and William Eden's widely read Principles of Penal Law (1771). They were also a central feature of the Parliamentary Committee of 1770, which was formed to address "the several Burglaries and Robberies that of late have been committed in and about the Cities of London and Westminster," and that gave rise to the first, largely unsuccessful attempts to substantially reduce England's capital code. ${ }^{88}$

What made burglary an especially urgent problem, as far as the execution levels of the mid-1780s are concerned, is demonstrated in Figure 4. Convicted burglars were usually more likely-and in the 1770s and 1780 s, far more likely - to be hanged than were convicted robbers. In September 1782, when the government announced a policy of refusing

between robbery and burglary convictions prevailed in $1730-49$ as in $1750-67$, save for 1734 (when they almost matched) and 1735 (when burglary convictions outnumbered those for robbery 4:3); See Execution and Pardon http://hcmc.uvic.ca/.

88. Commons Journals 32 (1768-70): 784; Radzinowicz, History, I:301-13, 425-46; and Beattie, Crime and the Courts, 548-59. 


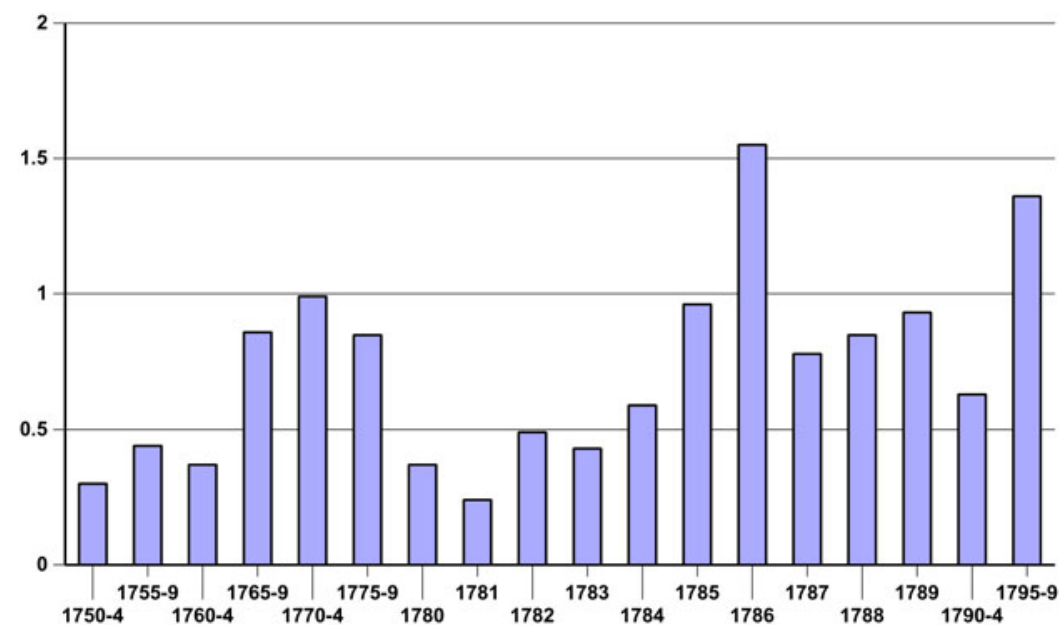

Figure 3. Old Bailey: burglary as a proportion of robbery convictions, 1750-99. Source: Execution and Pardon: Capital Convictions at the Old Bailey, 1730-1837. http:/hcmc.uvic.ca/.

pardons in London to anyone convicted of "robberies ... attended with acts of great cruelty," that resolution was made at the midpoint of a period (1779-84) in which robbery convictions were soaring by comparison with those for burglary (Figure 2). In practice, however, the immediately subsequent execution rates for robbery (1783-4) were among the lowest known before the last decade of the eighteenth century, whereas those for burglary were invariably high (Figure 4). Between 1780 and 1785, by comparison, and especially after 1783 , convictions for burglary soared. ${ }^{89}$ In 1786 - the year of the Felons Anatomy bill - they enormously exceeded convictions for robbery for the first time in the memory of living contemporaries (Figures 2 and 3). This confluence of robbery and burglary convictions - which appears to have been unanticipated by government in September 1782 - conjoined with a swift and substantial resurgence in the execution rate for robbery after 1784 on top of a persistently high execution rate for burglary, were the main factors in producing the unprecedented number of hangings in London between 1785 and 1787 (see Figure 1).

89. The government seems soon to have realized that burglary was again becoming a problem that needed to be tackled more effectively. In the summer of 1783 , an act was passed making any person who was apprehended in possession of implements for burglary or housebreaking subject to punishment under the Vagrancy Laws (23 Geo. III, c. 88). The background and operation of this measure are discussed in Audrey Eccles, Vagrancy in Law and Practice under the Old Poor Law (Farnham: Ashgate, 2012), 15, 153-6. 


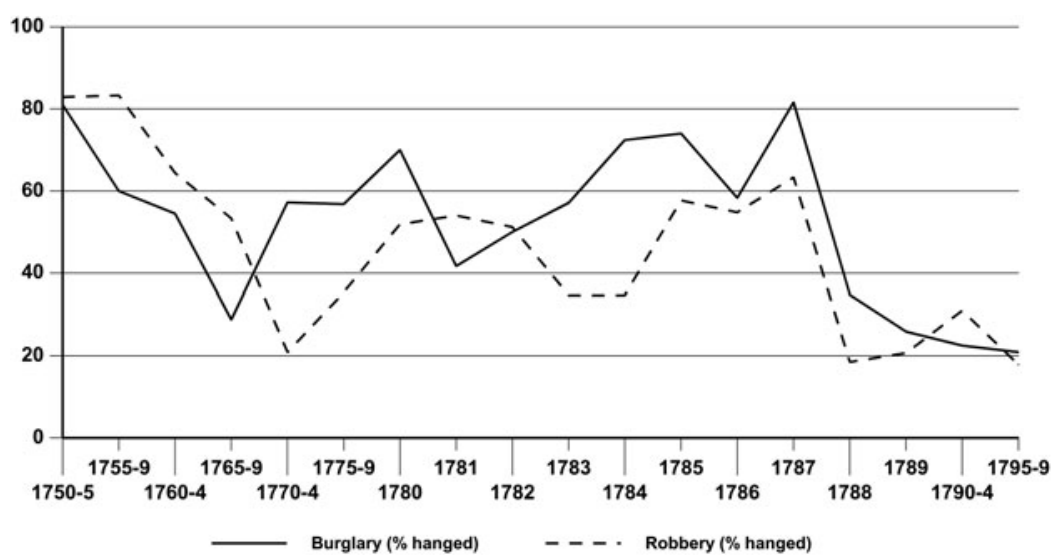

Figure 4. Old Bailey execution rates: burglary and robbery, 1750-99. Source: Execution and Pardon: Capital Convictions at the Old Bailey, 1730-1837. http:// hcmc.uvic.ca/.

As late as February 1787, the City of London was still seeking to impress upon government its continuing and particular concern about "the increase of burglaries" in the metropolis. ${ }^{90}$

In the face of such alarming heights of criminal convictions, the government was unwilling to reduce the level of executions, as many voices in the press demanded they should, until it could find an effective means to reduce conviction levels for the worst categories of persistent criminality: robbery (a perennial problem), and burglary (one of newly formidable dimensions). Therefore, it is suggestive, when notice was first given to the Commons in early April 1785 that the government was preparing a police bill for the metropolis, that the man who gave that notice-William Selwyn, a lawyer (and cousin of Lord Sydney) who seems often to have drafted the home secretary's criminal legislation-declared the measure to be self-evidently necessary in light of "the alarming increase of burglaries and street-robberies" in London. ${ }^{91}$ At this point, its proposed title was "a Bill for the more effectually apprehending and bringing to punishment, such persons as shall [be] found [to] be concerned in Burglaries and Highway Robberies." 92 As has been mentioned, the scope of the bill that was finally presented two months later was far more extensive than merely

90. The World, February 21, 1787.

91. London Chronicle, April 7-9, 1785; NA, HO 42/5, f. 46; and Namier and Brooke, eds., History of Parliament, III:421.

92. The Times, April 9, 1785. 
"apprehending and punishing" robbers and burglars. Nevertheless, the ultimate objective was the same: to significantly reduce the number of people who were now paying the ultimate price for such crimes.

Finally, Wilberforce and Pitt were not alone in favoring postmortem dissection as a punishment for hanged felons other than murderers. Edward Thompson, the man with overall command of Britain's naval interests on the African coast, and with whom the government was consulting as to the prospects of establishing a convict settlement there, had proposed the idea to Lord Sydney in April 1785, and for many of the same reasons that underpinned the 1786 bill:

The Many Executions of Late, and the increase of Crimes and Criminals, have so greatly alarmed Society in general, that any mode which might be introduced to lessen the one and spare the other will be highly acceptable to the state and the nation. By a long attention to the last confessions of our Malefactors, I have often discovered a greater solicitude about the body than the soul: and that they have always confessed more dread at the dissection of their dead bodies than any particular distress about the death on the Gallows, which Leads me to recommend ... ordering every body for Dissection that was executed. ...

Besides, my Lord, it might be a means of leaving our dead Friends at peace in their Graves. For at present, for the want of subjects for the Surgeons, There are not less than two bodies a day furnished by the Resurrection men for dissection, at two Guineas each .... ${ }^{93}$

Michael Angelo Taylor, the MP for Poole (Dorset), also agreed with much of this. In 1785, Taylor was identified in the London press as the leading parliamentary proponent of the Police Bill. The following year, he also took a leading role, alongside Wilberforce and Duncombe, in moving the Felons Anatomy Bill..$^{94}$ Taylor therefore provides another direct connection between the failure of 1785 and the proposal of 1786. For Taylor, a strategy for enhancing the deterrent impact of executions may even have had a paternal connection. Less than three years earlier, his father, the eminent architect and Sheriff of London, Sir Robert Taylor, had been the original mover of the proposal to abolish executions at Tyburn in favor of a more stylized and controlled execution ritual conducted immediately outside Newgate prison. That measure, subsequently adopted in other parts of the country during the ensuing years, can also plausibly be read as

93. NA, HO 42/6, ff. 335-36. For Thompson, see Christopher, Merciless Place, 309-22, which also cites Thompson's copy of this letter (National Maritime Museum, THM/6) at 312 .

94. Commons Journals 41 (1786): 815; Namier and Brooke, eds., History of Parliament, III:517; The Times, June 20, 1785, and June 21 1785; and The Gazetteer, June 22, 1785. 
an effort to make execution more formidable and forbidding in its immediate appearances - more effective a deterrent - and thereby holding out the ultimately humane prospect of reducing both the number of capital convictions overall and the need for large-scale execution scenes. It did not work out that way, but it was meant to do so. ${ }^{95}$

\section{The Contingency of "Humanitarian" Measures}

All of this serves as a reminder that the history of humane developments within any society and culture is by no means a straightforward, unidirectional phenomenon. It is not only, as Norbert Elias noted of "the civilizing process," that there are phases of substantive reversion as well as progress in any given narrative. ${ }^{96}$ We must also appreciate that the relative "humanity" of certain measures is often contingent upon the specific contexts of a given historical moment. In 1786 many officials genuinely believedhowever preposterous that belief may look to later observers - that penal measures whose immediate impacts might seem unacceptably dreadful, arguably even by the standards of their own age (as Loughborough maintained), would nevertheless serve humane purposes when viewed in the larger perspective. Such beliefs may even have been entertained by men such as William Wilberforce, whose later credentials as a standard bearer of humanizing values otherwise seem more indisputable. The Felons Anatomy Bill would have imposed a more fearsome mode of capital punishment for people convicted of the most serious categories of crime next to murder, but it appears to have been intended to apply that punishmentand perhaps execution at all - to a smaller number of people than were being executed in the years immediately preceding its introduction. Moreover, by specifically reserving the option of rejecting applications by the surgeons for most types of felons, it also left open the means of ultimately reducing the scale of such aggravated executions once circumstances permitted. And finally, it is important to note that the bill's most immediate object - the provision of a significantly larger number of corpses for anatomical study than were currently available by legal means - meant to serve another humane purpose: to enable surgeons to

95. Simon Devereaux, "Recasting the Theatre of Execution: The Abolition of the Tyburn Ritual," Past \& Present 202 (2009): 127-74 (at 165). For a more detailed and sophisticated reading of the cultural underpinnings of the new execution ritual, see Steven Wilf, "Imagining Justice: Aesthetics and Public Executions in Late Eighteenth-Century England," Yale Journal of Law and the Humanities 5 (1993-94): 51-78.

96. Pieter Spierenburg, The Broken Spell: A Cultural and Anthropological History of Preindustrial Europe (New Brunswick: Rutgers University Press, 1991), esp. ch. 1, 7; and Spierenburg, "Punishment, Power, and History: Foucault and Elias," Social Science History 28 (2004): 607-36. 
make their incisions into the bodies of conscious individuals as accurate, and therefore as swift, as possible. The needs of medical science provided a necessary spur to the Felons Anatomy Bill; the execution crisis of the 1780 s, and the intense arguments that it provoked, were its sufficient cause. ${ }^{97}$

If this vision of a Wilberforce who was ready to make fine-grained distinctions in the pursuit of humanitarian aims still seems puzzling, it might finally be noted that he appears to have been decisively compelled by the "emergency" of the moment. Only ten years later, when another bill for "Anatomizing the Bodies of Felons executed for Burglary or Highway Robbery" was proposed, neither he nor Taylor appears to have spoken on its behalf, and it was immediately rejected by the House of Commons. ${ }^{98}$ Both men presumably felt that the cruelties inherent in such a measure now loomed decisively larger than any of its potentially humane effects. ${ }^{99}$ Such a feeling would have been reinforced by the fact that, by the mid-1790s, both capital convictions and executions in London had fallen to their lowest levels in thirty years (see Figure 1), drastically reducing any impetus for such a bill so far as the needs of criminal justice were concerned. The other intensely felt pressures of 1786 had similarly abated a decade later. The first anatomy bill had been proposed in the wake of the collapse of the two principal strategies that government had deemed essential to an effective system of criminal justice: the full-scale resumption of convict transportation and the reform of London policing. By 1796, both matters had been substantially resolved, the former by the settling of Botany Bay in 1788 and the latter by passage of the Middlesex Justices Act in $1792 .{ }^{100}$ As crime was no longer so pressing a problem as it had been ten years earlier, and adequate means both to prevent and to punish it had (for the time being at least) been achieved, the space had now opened for a more decided expression of humanitarian distaste for a measure that now had no compelling rationale other than the

97. In contrast, Richard Ward maintains that "The statutory intentions of Wilberforce's 1786 bill were medical, not judicial" ("Criminal Corpse," 69; emphasis in original).

98. Commons Journals 51 (1795-6): 499; and Cobbett, Parliamentary History 32 (1795-97): 918-22; the most detailed published account of the exchanges in the Commons on this occasion appears to be William Woodfall, An Impartial Report of the Debates that Occur in the Two Houses of Parliament (London: T. Chapman, 17941803), 1796/3, 399-404.

99. Both may have remained passively supportive of the anatomists, however. When a bill to make grave robbing a crime was proposed the year before, Wilberforce's support for it was merely lukewarm (Whitehall Evening Post, March 17-19, 1795), and Taylor actually tried to squelch it (The Times, April 24, 1795).

100. For the Middlesex Justices Act, see the relevant passages in the works cited at note 39 . 
desires of the medical establishment for more anatomical subjects. The immediate rejection of the proposed Anatomy Bill of 1796, in contrast with the near success of that of 1786 , confirms that this latter factor could never, in itself, have been sufficient to ensure success.

\section{The Proclamation Society and Government}

There was perhaps one more compelling reason why Pitt's government had been so willing to take Wilberforce's anatomy proposal in hand in June 1786. It was at this exact moment that a revised version of the 1785 Police Bill, which Pitt had promised to introduce, was being quietly shelved. The principal reason for doing so appears to have been, as with the penitentiary project beforehand, the sheer scale of the costs that would be involved. ${ }^{101}$ The government may also have now appreciated that any preventative measure that addressed the problem of crime in London alone was insufficient. Crime and its effective punishment had become an equally urgent problem - and an unprecedentedly persistent one, years beyond the end of the most recent war-outside the capital, and certainly in the counties of southeastern England. An expensive and politically contentious overhaul of the London magistracy might perhaps have reduced metropolitan levels of capital criminality and execution over the long run. A sharp enhancement of the horrors of execution among a select group of capital convicts could have done so sooner, and throughout the nation at large. Attention to the now national scale of the problem of crime also helps to explain Pitt's support for Wilberforce's second strategy for reducing the scale of executions in England.

This second effort is considerably better known to historians; it is also much more easily reconciled with Wilberforce's spiritual awakening of November 1785. Having failed to convince parliament that a more selective but dramatic exercise of capital punishment might be an effective and appropriate means to this end, Wilberforce and the government returned to a revised strategy for preventative policing, this time conceived on a national rather than a merely metropolitan scale. The basic animating principle remained the same as that adopted by government for London in the autumn of 1782: to prevent the development of serious criminality in its

101. The Times, July 12, 1786; and Morning Chronicle, September 6, 1786. Most historians of policing assume that the Police Bill was dropped after 1785 and not revived until the passage of the Middlesex Justice Act in 1792, but at least two documents indicate that it remained a live prospect for a year thereafter (Brotherton Library [Leeds University], Sydney/ Townshend Papers K9; National Archives of Scotland, GD 51, 1/264/4). 
nascent stages by the more determined prosecution and punishment of petty offenses. On June 1, 1787 the king issued "A Proclamation for the Encouragement of Piety and Virtue, and for the preventing and punishing of Vice, Profaneness and Immorality." Lamenting "the rapid Progress of Impiety and Licentiousness, and that Deluge of Profaneness, Immorality, and every Kind of Vice, which, ... hath broken in upon this Nation," the Proclamation required all subjects to obey, and all magistrates to enforce, the laws against profanation of the sabbath, excessive drinking, blasphemy and cursing, public gaming, licentious gatherings, and lewd publications. All English people, both rulers and ruled, were to be regularly reminded of their duties four times yearly by the reading aloud of the Proclamation at assizes and quarter sessions. ${ }^{102}$

By this means, Wilberforce and the government meant, among other things, to reduce the scale on which capital punishment was now being practiced. "The barbarous custom of hanging has been tried too long, and with the success that might be expected from it," Wilberforce told reformer and fellow Yorkshireman Christopher Wyvill. "The most effectual way to prevent greater crimes is by punishing the smaller, and by endeavouring to repress the general spirit of licentiousness, which is the parent of every species of vice." 103 This most immediate purpose of the Proclamation was also readily apparent to sympathizers. "It gives me pleasure," one wrote to Wilberforce soon after, "to find that you join in the ideas of many humane and thinking men, in reprobating the frequency of our Executions and the sanguinary Severity of our Laws. They have long shocked the Feelings of Humanity, and are totally inefficacious as to the obtaining the Object all penal severity ought to aim at, namely the Deterring others from committing Like Offenses." 104 In other words, as Richard Follett has noted, "the connection Wilberforce made between moral reform and the reduction of crime [was] central" to this new endeavor. ${ }^{105}$

As noted earlier, this basic strategy was not new. After William and Mary issued a proclamation "for the encouragement of piety and virtue, and the preventing and punishing of vice, profaneness, and immorality" in January 1691-92, similar ones were issued at the accession of each

102. London Gazette, May 29 -June 2, 1787.

103. Life of Wilberforce, I:131.

104. William R. Perkins Library (Duke University), William Wilberforce Papers (4th Duke of Manchester to Wilberforce, September 18, 1787).

105. Follett, Evangelicalism, Penal Theory and Law Reform, 94; see also Roberts, Making English Morals, 32. 
new monarch, from Queen Anne in 1702 to Victoria in 1837. ${ }^{106}$ Their apparently close symbolic linkage with royal authority may date from the "Proclamation against vicious, debauch'd, and prophane persons" issued by Charles II soon after his return from exile in May 1660, which demanded that all the king's subjects should "cordially renounce all that Licenciousness, Prophaneness, and Impiety, with which they have been corrupted and endeavored to corrupt others, and that they will, hereafter, become examples of Sobriety and Virtue ...". The newly restored king promised that his government would "not exercise just Severity against any other Malefactors, sooner, than against Men of dissolute, debauch'd, and prophane Lives" and professed his hope that "the displeasure of good Men towards them, may supply what the Laws have not," to which end he required all local officials "to be very vigilant and strict in the discovery and prosecution of all Dissolute and Prophane Persons, and such as Blaspheme the Name of God, by prophane Swearing and Cursing, or revile or disturbe Ministers, and despise the Publick Worship of God ...". ${ }^{107}$ The issuing of this proclamation may have been an explicit bid, following the collapse of Cromwell's regime, to win the support of moderate Puritans for the restored royal order. The first comprehensive morals reform measure - "for the more vigorous and effectual putting in Execution the Laws against Sabbath-breaking, Swearing, Drunkenness, and Whoredom, with the greatest Severity" - had been issued by the Council of State in November 1649, perhaps with a view to enhancing its claims to godly legitimacy following the trauma of Charles I's execution earlier that year. ${ }^{108}$

The Proclamation of 1787 was a significant departure from its eighteenth century forbears, however, in at least one notable respect. It was the first comprehensive proclamation for a reformation of manners to be issued outside the occasion of a monarchical accession. This timing reflected not only the emergency caused by the execution levels in London and elsewhere, but also several recent and uniquely powerful developments in English politics and society. One of these was a profound belief, among a middle class becoming more and more conscious of its economic and political power, that direction of the nation's affairs at the very highest levels, and not just the behavior of the people at large, was profoundly in need of

106. Robert Steele, and James, Earl of Balcarres, eds., A Bibliography of Royal Proclamations, 1485-1910, 4 vols. (1910-13; reprint ed., New York: Burt Franklin, 1967), I:489a (\#4076), 514a (\#4314); IV:4, 32, 97, 101, 276, 301, 333.

107. A Proclamation Against Vicious, Debauch'd, and Prophane Persons (May 30, 1660) (Wing [2nd ed., 1994] C3227 / Thomason /669.f. 25 [36]).

108. Steele and Balcarres, eds., Bibliography of Royal Proclamations, I: 349a (\#2882); see also Cromwell's encompassing proclamation of August 9, 1655 at I:369b (\#3057). 
correction. ${ }^{109}$ That perception was animated by several prominent features of the national public discourse during the 1780s: the catastrophe of the war with America, the first major conflict in a century which Britain had indisputably "lost," the enormously inflated national debt left in its wake, the political and constitutional crisis of 1782-84, levels of serious criminal conviction that had remained high far longer than might plausibly be explained solely by postwar social-economic dislocation, and a rapidly maturing consciousness, among many sectors of the nonelite propertied classes, that traditional aristocratic rule was inherently corrupt and essentially corrosive of the national public temper. ${ }^{110}$ "The Scriptures teach us to consider national judgments, as punishments for national sins," the evangelical educationist Sarah Trimmer wrote in September 1783. "[O]ur nation at present, is notorious for so many vices, that we may expect calamities at every turn." 111

Following his conversion experience of November 1785, Wilberforce would have shared Trimmer's sense of God's providences at work in the nation at large. The crusade against the slave trade, in which he took so prominent a part, has been plausibly presented as a project to reclaim moral authority from Britain's erstwhile colonists in America. ${ }^{112}$ The many personnel whom the antislavery movement shared with the Proclamation Society suggest that the latter must also have been conceived as part of a larger project for the re-moralization of English society. For Wilberforce, as for many others, commitment to a reformation of manners was also driven by a deep conviction that all men and women must ultimately answer for their personal omissions and failings at the seat of judgment. As he remarked to one young woman in November 1787, "the

109. For middle-class attacks on the moral decay of aristocratic rule during this era, see Paul Langford, Public Life and the Propertied Englishman, 1689-1798 (Oxford: Clarendon Press, 1991), 540-48, 569-81; and Donna T. Andrew, Aristocratic Vice: The Attack on Duelling, Suicide, Adultery, and Gambling in Eighteenth-Century England (New Haven: Yale University Press, 2013).

110. See the anonymous observations in "Internal Police of this Kingdom very much neglected," Gentleman's Magazine 55 (1785): 951-52. For these wider contexts, see Innes, "Politics and Morals," 181-87; and Roberts, Making English Morals, 24-33.

111. Some Account of the Life and Writings of Mrs Trimmer, with Original Letters and Meditations and Prayers, Selected from Her Journals, 2 vols. (London: F.C. and J. Rivington, J. Johnson and Co., and J. Hatchard, 1814), II:224.

112. Linda Colley, Britons: Forging the Nation, 1707-1837 (New Haven: Yale University Press, 1992), 350-60; and Christopher Leslie Brown, Moral Capital: Foundations of British Abolitionism (Chapel Hill: University of North Carolina Press, 2006). For doubts on this perspective, however (and an unusually optimistic interpretation of the 1780s), see Seymour Drescher, "The Shocking Birth of British Abolitionism," Slavery and Abolition 33 (2012): 571-93. 
Christian's motto should be, 'Watch always, for you know not in what hour the Son of Man will come." Similarly, in cautioning his own sister against the pleasures of theater going, he apologized for any offense his advice might give, but emphasized "that I see the vanity of all pursuits of this life, and with somewhat of a humble hope, through the mercies of my Redeemer, look forward to a better.... [W] hen I reflect that I shall have to account for my answer to [you] at the bar of the great Judge of quick and dead, I cannot, I dare not, withhold or smooth over my opinion."113 So might many of his fellow evangelicals and Proclamation Society members have replied if challenged to explain the formal severities of their moral position.

The basic idea for some such initiative as the Proclamation was in circulation almost immediately after the failure of the Metropolitan Police Bill in June 1785. One of its first prominent advocates was Thomas Bayley, Chairman of the Lancashire Quarter Sessions and the presiding force in that county's reconstruction of its county prison and houses of correction. ${ }^{114}$ In addressing the grand jury at the quarter sessions on July 21, 1785 , Bayley read out "the royal proclamation against vice, profaneness and immorality" (presumably that which had been issued at the king's accession a quarter-century earlier) and noted that "it contains excellent and important instruction for us all." In announcing the county bench's unanimous resolve "to provide a New House of Correction and Penitentiary House" along the lines prescribed by the 1779 Penitentiary Act, Bayley also returned to a theme that the solicitor general had emphasized in presenting the Police Bill to parliament: "Our horror is almost continually excited by the dreadful accounts of multitudes of poor creatures who are hanged almost in childhood for the blackest crimes. At the fatal tree they all tell us - that they have never been taught to know God and their duty; have never been corrected for their early wickedness, - but been abandoned by their parents, and suffered at once to plunge headlong into vice and destruction.- - How do these wretches punish us, by their villanies, for their neglected education?" Bayley saw a revitalized Sunday school movement as both essential to the nation's spiritual renewal (in the manner of Sarah Trimmer) and a central component of a more comprehensively effective approach to preventive policing. ${ }^{115}$

113. Robert Isaac Wilberforce, and Samuel Wilberforce, eds, The Correspondence of William Wilberforce, 2 vols. (London: John Murray, 1840), I:46, 50.

114. Margaret DeLacy, Prison Reform in Lancashire, 1700-1850: A Study in Local Administration (Stanford: Stanford University Press, 1986), ch. 3-4; and George Fisher, "The Birth of the Prison Retold," Yale Law Journal 104 (1995): 1235-1324.

115. Morning Chronicle, August 25, 1785 (emphasis in original). 
Similar advocacy of renewed efforts to rigorously school the morals of the English people soon became a regular theme of newspaper correspondence. ${ }^{116}$ Sometime in mid-1786, An Account of the Reformation of Manners, originally published in 1699, was reissued, "with some Remarks adapted to the present Period, and an Abstract of various Penal Laws," by a society established in Huddersfield, Yorkshire, one with which Wilberforce may have been associated. ${ }^{117}$ In April 1787, the grand jury at the Old Bailey presented a formal memorial to the City of London, lamenting the widespread conduct of business on Sundays, which they perceived to be a "great encouragement of vice and immorality, and consequently tending to the encrease and multiplying the melancholy business" of the criminal courts. Two months later, following issuance of the royal Proclamation, the City ordered copies of it to be "stuck up in the most conspicuous parts" of the town. ${ }^{118}$

Whenever precisely he took up the cause, Wilberforce's close access to Pitt's government gave the movement extra influence, at least for a time. Home secretary Sydney circulated the Proclamation, first to all the chief magistrates of counties, then soon afterwards to all the high sheriffs, ordering them "to take the most early opportunity of convening the magistrates within" their counties "and enjoining them, in the strongest terms, to pursue the most effectual methods for putting the laws in execution" against "the profanation of the Lord's day, drunkenness, swearing, and cursing, and other disorderly practices." Unlike the Proclamation itself, which emphasized immorality and vice in general, Sydney's circular took particular notice of the fundamentally related problem of crime: "of the depredations which have been committed in every part of the kingdom, and which have of late been carried to such an extent as to be even a disgrace to a civilized nation, ....". 119

116. Ibid., August 30, 1785, September 3, 1785, October 6, 1785, November 14, 1785, and September 9, 1786; St James' Chronicle, November 10-12, 1785; The Times, October 24, 1786; Gentleman's Magazine 56 (1786): 257-58; Yorkshire Magazine 1 (1786): 306-8; and County Magazine 1 (1786-87): 144, 322. See also the "Considerations respecting the Police of London and Westminster" submitted by the correspondent "Varro" to the Morning Chronicle, December 12, 1785, December 16, 1785, December 27, 1785, and January 4, 1786.

117. Critical Review 62 (1786): 478; and Monthly Review 75 (1786): 382-83. See also Life of Wilberforce, I:130; and Coupland, Wilberforce, 49-50.

118. Morning Chronicle, April 26, 1787; and Gentleman's Magazine 57 (1787): 545.

119. Morning Chronicle, July 21,1787; The Times, September 13, 1787; and British Library, Add MS 35682 (Hardwicke Papers), ff.383-84. The most recent account of the Proclamation Society maintains that the sorts of direct policing activities that were emphasized in the government's circular - a "limited secular foray against the post-war crime 
Previous governments had similarly tended to support reformation of manners movements when such concerns appeared to dovetail with their own. The most strikingly active and sustained predecessors of the Proclamation Society, the Societies for the Reformation of Manners of the early eighteenth century, had enjoyed royal support during the Augustan era: partly because those years, too, were characterized by a crisis of large-scale criminal convictions (especially in London); but also because both monarchs of the time had compelling political and personal interests at stake. William III was concerned to give his seizure of the throne the appearance of divine sanction; Queen Anne may have been inspired more simply by a genuine desire to publicly manifest her own personal piety. ${ }^{120}$ The $1730 \mathrm{~s}$ saw a resurgence of government interest, partly from the concerns of public commentators - pious and otherwise-for the particular problems of alcohol-driven immorality during the years of the "gin craze," but also from a pragmatic desire on the part of Sir Robert Walpole to use liquor licensing to boost government revenue, especially in the wake of his failed Excise bill of $1734 .{ }^{121}$ The early 1750 s gave rise to yet a third concentration of moral reform agitation, both within parliament and among society at large, driven not only (and again) by high crime levels, but also by a general sense of God's judgments upon English society, reflected not least in the reaction to the unprecedented occurrence of two earthquakes in London in $1750 .{ }^{122}$

wave"-were "only belatedly (and never systematically)" taken up by the Society itself (Roberts, Making English Morals, 37, 45-46).

120. G.V. Portus, Caritas Anglicana: or, An Historical Inquiry into those Religious and Philanthropical Societies that Flourished in England between the Years 1678 and 1740 (London: A.R. Mowbray, 1912); D.W.R. Bahlman, The Moral Revolution of 1688 (New Haven: Yale University Press, 1957); Robert B. Shoemaker, Prosecution and Punishment: Petty Crime and the Law in London and Rural Middlesex, c.1660-1725 (Cambridge: Cambridge University Press, 1991), ch. 9; Shoemaker, "Reforming the City: The Reformation of Manners Campaign in London, 1690-1738," in Stilling the Grumbling Hive: The Response to Social and Economic Problems in England, 1689-1750, eds. Lee Davison, Tim Hitchcock, Tim Keirn and Robert B. Shoemaker, (Stroud \& New York: Alan Sutton/St Martin's Press, 1992), 99-120; Tony Claydon, William III and the Godly Revolution (Cambridge: Cambridge University Press, 1996); and Kevin Sharpe, Rebranding Rule: The Restoration and Revolution Monarchy, 1660-1714 (New Haven: Yale University Press, 2013), pts. iii-iv (esp. 519-20).

121. Edward Carpenter, Thomas Sherlock, 1678-1761: Bishop of Bangor 1728, of Salisbury 1734, of London 1748 (London: Society for the Propagation of Christian Knowledge, 1936), ch. 9; Lee Davison, "Experiments in the Social Regulation of Industry: Gin Legislation, 17291751," in Stilling the Grumbling Hive, 25-48; and Patrick Dillon, The Much-Lamented Death of Madam Geneva: The Eighteenth-Century Gin Craze (London: Review, 2002).

122. Carpenter, Thomas Sherlock, ch. 9; T.D. Kendrick, The Lisbon Earthquake (London: Methuen, 1957), ch. 1; Richard Connors, “"The Grand Inquest of the Nation': Parliamentary Committees and Social Policy in Mid-Eighteenth-Century England," Parliamentary History 
The Pitt government's support for the 1787 Proclamation can therefore be construed as simply a restatement of the October 1782 circular to London magistrates, additionally driven now by three years of the largest execution numbers in London in nearly two centuries, and intensive public arguments over both the morality and the efficacy of such displays. As we have already seen, all those executions were making little or no dent in the scale of criminal convictions at the Old Bailey. The government's support must also have now reflected a growing appreciation, during the intervening five years, that the problem of large-scale criminal convictions - straining beyond capacity the institutional resources even of some county authorities, such as those of Gloucestershire, Lancashire, and Oxfordshire, who were actively taking up the construction of largescale prisons on the penitentiary model — was no longer confined to the metropolis. ${ }^{123}$

There is little evidence that the support of government endured for very long after the Proclamation was issued in July 1787. The longer-term fortunes of the Proclamation Society and its mission have been detailed by other scholars, particularly Joanna Innes and Michael Roberts. ${ }^{124}$ As far as government interest in particular was concerned, subsequent developments soon reduced the Society's relevance as far as resolving the penal crisis of the 1780s was concerned. By the early 1790s, on the one hand (and as we have already noted with respect to the failed attempt to reintroduce the Felons Anatomy Bill in 1796), large-scale convict transportation had been resumed, and a substantial reformation of metropolitan policing

14 (1995), 285-313; Bob Harris, Politics and the Nation: Britain in the Mid-Eighteenth Century (Oxford: Oxford University Press, 2002), ch 7; Robert G. Ingram, "'The Trembling Earth is God's Herald': Earthquakes, Religion and Public Life in Britain during the 1750s," in The Lisbon Earthquake of 1755: Representations and Reactions, eds. Theodore E.D. Braun, and John B. Radner (Oxford: Voltaire Foundation, 2005), 97-115; and Rogers, Mayhem, esp. ch. 4, 7-8.

123. See the anonymous observations in "Internal Police of this Kingdom very much neglected," Gentleman's Magazine 55 (1785): 951-52. Detailed studies of local prison reform during these years include J.R.S. Whiting, Prison Reform in Gloucestershire, 1776-1820 (London: Phillimore, 1975); Whiting, A House of Correction (Gloucester: Alan Sutton, 1979); and David Eastwood, Governing Rural England: Tradition and Transformation in Local Government, 1780-1840 (Oxford: Clarendon Press, 1994), 242-60. For Lancashire, see the references in note 114 .

124. In addition to the references in notes 4-5, see Ian Bradley, The Call to Seriousness: The Evangelical Impact on the Victorians (London: Jonathan Cape, 1976), ch. 5; Edward J. Bristow, Vice and Vigilance: Purity Movements in Britain since 1700 (Dublin: Gill and Macmillan, 1977), ch. 2; and Jean N. Baker, "The Proclamation Society, William Mainwaring and the Theatrical Representations Act of 1788," Historical Research 76 (2003): 347-63. 
achieved. On the other hand, and sooner even than this, government had at last found an occasion on which to implement a dramatic and lasting reduction in the proportion of executions in London.

That occasion was King George III's first serious bout with porphyria, a congenital condition that manifested itself in symptoms of insanity, during the winter of 1788-89. The fate of each capital convict at the Old Bailey could not be determined until each of their cases had been reviewed by the king and the senior members of the cabinet at a meeting known as the Recorder's Report. ${ }^{125}$ Ever since George III had ascended the throne in 1760, the regular practice had been to hold one such meeting for each of the eight annual sessions at the Old Bailey. The king's incapacitation between early November 1788 and the end of February 1789, however, meant that the Recorder's Report that was at last convened on March 13, 1789 was obliged to review no less than forty-eight capital cases from four accumulated sessions. If the more usual execution rates that had prevailed at Recorder's Reports during the previous five years (anywhere from one- to two-thirds) were to be applied on this occasion, somewhere between sixteen and thirty-two people would have been hanged after this one. The cabinet came close to doing just this: it left fourteen people to die the following Wednesday morning, a number that would have ranked with the largest gallows displays seen in London during the last decade.

Then Pitt himself, and at least three other cabinet members (including the Lord Chancellor), had second thoughts. After consulting privately with them, Pitt persuaded home secretary Sydney to issue reprieves for five more of the condemned the night before they were to die, so that only nine people were hanged on March 18, 1789. That was still an imposing number for any one hanging day; but in the context of four accumulated sessions, nine people comprised a dramatically reduced execution rate by comparison with that produced by most other individual Recorder's Reports of the previous decade. ${ }^{126}$ At the same time, it says something

125. The origins and early practice of the Recorder's Report are analyzed in Beattie, Policing and Punishment, 346-62, 448-62. For accounts of its early nineteenth century practice, see Arthur Aspinall, "The Grand Cabinet, 1800-1837," Politica 3 (1938): 333-44; Gatrell, Hanging Tree, ch. 20-1; and Simon Devereaux, "Peel, Pardon and Punishment: The Recorder's Report Revisited," in Penal Practice and Culture, 1500-1900: Punishing the English, eds. Devereaux and Paul Griffiths (Basingstoke: Palgrave Macmillan, 2004), 258-84.

126. The numbers of condemned, and the timing and outcomes of Recorder's Reports, can all be determined using Execution and Pardon http://hcmc.uvic.ca/; the specific reprieve of March 17, 1789 is recorded at NA, HO 13/6, p.373. The numerical distribution of Old Bailey executions from 1783 to 1788 inclusive is provided in Devereaux, "England's 'Bloody Code' in Crisis and Transition," 87 (Figure 4). 
about the continuing support for maximum severity among other contemporaries, that Pitt felt obliged to defend this circumspect reduction in the scale of London executions. He assured Sydney (and through him, the king himself) that the "Lenity shown on this [particular] Occasion can give no Foundation of Hopes to those who might offend in future and will therefore in no degree interfere with the great End of Punishment [i.e., deterrence]." Pitt was careful to present this act of mercy principally as a means to avoid any display that might cast a shadow over public celebrations of the king's recovery. ${ }^{127}$

His assurance that this display of restraint would be an exception seems to have been disingenuous; such restraint soon after became the rule (see Figure 1). Following the failure of various other efforts to find a means to reduce the scale of execution displays in London, Pitt had seized upon a unique and unanticipated opportunity to bring them more closely into line with the respectable London public's distaste for large-scale execution scenes outside Newgate. ${ }^{128}$ That this reduction could be made to last must have stemmed from the news, received barely three weeks beforehand, that the government's efforts to resume large-scale convict transportation on a regular basis looked as though they would at long last succeed. In August 1786, a year after parliament had thwarted the African project, the government had announced its choice of Botany Bay as the site for a new convict settlement; nine months later, the First Fleet was sent out to establish it. ${ }^{129}$ Only three weeks before the Recorder's Report of March 1789, word finally reached London (via a Dutch ship returning from China) that the First Fleet had arrived safely. ${ }^{130}$ Restraint could at last be brought

127. Arthur Aspinall, ed., The Later Correspondence of George III, 5 vols. (Cambridge: Cambridge University Press, 1962-70), I:401-2; Clements Library, Pitt Papers 2 (William Pitt to Lord Sydney, March 16 and 17, 1789; the second of these two letters is the source of the quote). For another account of this important decision, see Hay, "Laws of God," $105-6$.

128. A report-by-report analysis suggests that the government had begun to reduce the scale of Old Bailey executions more than a year before the cabinet decision of March 1789. The people executed in 1788 comprised between only one-third and one-half of those capitally convicted, whereas those executed in 1787 had comprised between one half and two thirds. For most of 1789, however, the execution rate was as low as one seventh and never higher than 28\% (Execution and Pardon http://hcmc.uvic.ca/).

129. Accounts of the founding of Australia and the early phases of transportation are legion. Scholarly versions include A.G.L. Shaw, Convicts and the Colonies (London: Faber \& Faber, 1966), ch. 2-3; and Atkinson, Europeans in Australia, passim; two vivid popular accounts are Robert Hughes, The Fatal Shore (New York: Alfred A. Knopf, 1987), ch. 1-4; and Tom Keneally, The Commonwealth of Thieves: The Sydney Experiment (Sydney: Random House Australia, 2005).

130. Morning Chronicle, February 25, 1789. The official despatches from Botany Bay itself were received on March 26, 1789 (General Evening Post, March 26-28, 1789). 
to bear upon the gallows because the most imposing of secondary punishments was once more available.

The central importance of reliable transportation points toward a second reason why the government soon lost any active interest in promoting the Proclamation Society. The extent to which the Society's central objective, to punish petty offenses more consistently and effectively, could be realized must have varied from one part of the country to the next. One major reason for such regional variation was the extent to which the appropriate penal remedies for petty offences - new-style reformative prisons modelled on the regime set out in the Penitentiary Act-were available to local officials. This problem was explicitly recognized by the Society itself. In June 1789, it published, and distributed free of charge, pamphlets containing the relevant sections of John Howard's survey of prison conditions "to the Judges, Sheriffs, Gentleman of the Grand Juries, Magistrates, [and] Clerks of the Peace" of each assizes circuit of the country. ${ }^{131}$ Their aim was to inspire local authorities, through a mixture of cajolery and shame, to bring the standards of imprisonment at hard labor in their various gaols up to those deemed requisite by both law and the Society's purposes. It is unclear how far the Society's efforts may have accelerated the process by which prison reform, from one county to another, took place during the late eighteenth and early nineteenth centuries. ${ }^{132}$

The Society's determined advocacy of penitentiary-style prisons, however, must have proved an irritant to Pitt in at least one specific context. As has been mentioned, the London-based institutions proposed in the Penitentiary Act of 1779 had been explicitly abandoned in September 1782 and replaced by a focus on revitalized morals policing. The culminating measure in this alternative approach, the Metropolitan Police Bill of 1785 , had in turn foundered in parliament and been definitively abandoned the year after. Yet still, the problem of large-scale criminal convictions and executions persisted, and some people now questioned the wisdom of the

131. An Account of the Present State of the Prisons and Houses of Correction in the Northern Circuit, Take from a late Publication of John Howard, Esq. F.R.S., By Permission of the Author (London: the Society, 1789). Equivalent pamphlets are extant for the Home, Norfolk, Western, Midland, and Oxford circuits, as well as London and Westminster.

132. See also Roberts, Making English Morals, 54. General surveys of local prison reforms during this era include Robin Evans, The Fabrication of Virtue: English Prison Architecture, 1750-1840 (Cambridge: Cambridge University Press, 1982), ch. 4-6; Christopher Chalklin, English Counties and Public Building, 1650-1830 (London: Hambledon, 1998), ch. 9-10; and Allan Brodie, Jane Croom, and James O. Davies, English Prisons: An Architectural History (Swindon: English Heritage, 2002), ch. 2-3. For specific studies, see the references in notes 114 and 123. 
government's approach. "No man," one newspaper correspondent asserted in April 1786,

would believe it possible that, while at the end of every sessions at the Old Bailey, ten or twenty bold and active young men are hanged, ... there could exist an Act of Parliament, and that a very modern one, by the execution of which not only the lives of those unhappy men might be saved, but they might be made useful and industrious citizens. Such, however, is exactly our case at present, and while the street before Newgate is every six weeks a scene of the most horrid carnage, the statute of 19 George III for erecting the Penitentiary Houses is suffered to remain, like a mere Utopian project, a useless ornament to the statue book. ${ }^{133}$

Just two days after the Lords had thrown out the Felons Anatomy Bill, the penitentiary commissioners wrote to Pitt in the "Understanding [that] the Penitentiary Act is at present under your Consideration" and assuring him that they could now propose a less expensive scheme than that which had been rejected four years earlier. ${ }^{134}$ Wilberforce himself, as one might expect, was a supporter of the project and occasionally pressed Pitt on the matter. He must have perceived, in his friend's sinuously worded replies ("Of the Penitentiary Houses what can I say more? But in due time they shall not be forgotten"), the essential quiescence of the central government on the matter. ${ }^{135}$

Pitt continued to quietly neglect the issue, not only because of its enormous prospective costs, but also because London officials (and those of other counties) continued to press for transportation rather than imprisonment as the punishment of choice for any capital convicts who were not to be hanged. ${ }^{136}$ Once transportation was again more or less fully established by the spring of 1789, the government's passive but persistent resistance to the penitentiary project could be more determinedly reasserted. New pressures from the Society to continue pursuing it must have been an

133. Morning Chronicle, April 24, 1786; see also letters in the issues for March 29, 1786 and March 24, 1787, both written by the prison-reformer magistrate of Lancashire, Thomas B. Bayley.

134. Clements Library, Sydney Papers 13 (Gilbert Elliot to William Pitt, July 7, 1786).

135. A.M. Wilberforce, ed., Private Papers of William Wilberforce (London: T. Fisher Unwin, 1897), 16, 21 (quote). Wilberforce may have been of the view, expressed in a newspaper of that time, that the Police Bill could not serve the purposes of prevention "Till some mode of employing rogues is devised" (General Evening-Post, June 28-30, 1785).

136. "County of Berks, March 2d, 1791. // It is Resolved, by the HIGH SHERIFF and GRAND JURY, ....That the Members [of parliament] for the County and the Boroughs within it, be desired to oppose any Bill that tends to retain Convicts sentenced to transportation in Penitentiary Houses, or elsewhere within the county" (The Times, March 8, 1791). For London's firm opposition until the 1790s at least, see note 22. 
unwelcome and unanticipated concomitant of an alliance that had originally been cultivated primarily with a view to ensuring the more rigorous prosecution of petty offenders. As far as Pitt's government was concerned, the extent to which penitentiary-style prisons were used to achieve that end was for local officials to decide for themselves. By the summer of 1787, well-publicized examples of such locally realized regimes were already available in several counties. There was no need for the central government to return to a project that was best left to local officials to pursue in their own good time, and at their own expense. ${ }^{137}$

Admittedly, much of the argument presented here remains stubbornly in the realm of the inferential. Precious few documents have survived to provide specific and sustained evidence as to the patterns of thinking and the relative calculations that animated Pitt and his colleagues from one moment to the next as they navigated a penal crisis that must sometimes have seemed unending. In the short term, the government's primary motive for backing the Proclamation Society may have been eliminated only a year and a half later, when it found plausible grounds on which to reduce the scale of Old Bailey executions. Changing experiences in policing and punishment over the longer term would only have further reduced the interest of government in the Society and its mission. By the mid-1790s, criminal convictions had at last declined markedly, at least by comparison with the appalling heights of the mid-1780s. By that time, under the combined impetus, on the one hand, of renewed parliamentary pressure for the penitentiary project in the early 1790 s, and the threat of radical political activism on the other, the government had succeeded in passing a revised version of the Metropolitan Police Bill in the spring of $1792 .{ }^{138}$ Its workings were confined to the county of Middlesex alone, but as this was by far the largest geographical and demographic component of the metropolis, the Act may have been reckoned to be no small success. By the time the county of Middlesex opened a vast new house of correction at Cold Bath Fields in 1794, the adamancy of that county's officials that transportation alone was the only acceptable punishment next to death was at last relaxing. From July 1793 onwards, many capital convicts at the Old Bailey-usually women, and either elderly or very young men-received pardons on condition of imprisonment at hard labor rather than transportation to

137. The architects of the Penitentiary Act itself had clearly expected the regime that it described to be adopted by county authorities in just such a gradualist fashion (Devereaux, "Making of the Penitentiary Act," 429-33).

138. Paley, "Middlesex Justices Act," ch. 7-9; Beattie, First English Detectives, 159-205; Simon Devereaux, Convicts and the State: Criminal Justice and English Government, 17501810 (forthcoming), ch. 10. 
New South Wales. ${ }^{139}$ By that time certainly, and perhaps earlier, Pitt's government must no longer have felt any pressing need to actively support the activities of the Proclamation Society, at least so far as they related to the problems of crime and punishment in London. ${ }^{140}$

\section{Conclusion}

Were Wilberforce and Pitt "inexperienced humanitarians"? Not insofar as the two proposals explored here were intended, among other things, to reduce the enormous numbers of people being sent to the gallows by the mid-1780s. Nevertheless, real pressures against the accomplishment of these measures were exerted by other considerations: anxiety about persistently high levels of violent crime; a consequent sympathy, less for the plight of the condemned criminal, and more for Madan's ideas of maximum severity; and the reluctance of Pitt's government to take a leading role in aggressively promoting the spread of that penal institution - the penitentiary - which people such as Wilberforce thought was most centrally expressive of a genuinely reformist and "sympathetic" mode of punishment. Under such circumstances, it was all but impossible to achieve legal reforms that might express humanitarian concern in as uncomplicated and full-blooded a manner as we might expect of an age in which some people were placing a growing social and cultural value upon such ideals as "sympathy" and "feeling."

One of the complicating factors at work may simply have been generational. Perhaps the young Wilberforce and Pitt were innately more willing to reduce the use of the gallows than was a prevailing older generation that included most of the high court judges and Pitt's own home secretary, Lord Sydney. That willingness may have reflected the younger men's less prolonged experience of London crime. By the mid-1780s, Sydney, the judges, London's aldermen, and other officials involved in deploying the gallows had lived through two decades of unusually high levels of criminal conviction (see Figure 1). Wilberforce and Pitt, both born in 1759, had spent their childhood and youth far from the capital. Pitt only moved to London in December 1779; Wilberforce arrived the year after, following his election to parliament. ${ }^{141}$ Although both men would have lived through that particularly tremendous surge in crime that accompanied

139. Execution and Pardon http://hcmc.uvic.ca/

140. The Society's role in the struggle against revolutionary ideals during the 1790 s, however, may well have been another matter (see Roberts, Making English Morals, ch. 2).

141. John Ehrman, The Younger Pitt: The Years of Acclaim (London: Constable, 1969), 20; and Hague, Wilberforce, 36. 
the end of the war, they probably lacked that sense, which their elders would have possessed, of all the preceding years of high levels of criminality in the metropolis. Perhaps this made them more capable of imagining a less determined reliance on the law's ultimate exaction.

At the same time, however, Wilberforce and Pitt may not have been of the same mindset on all aspects of criminal justice. We have already seen that this was the case with respect to the Proclamation Society and the closely related issue of penitentiary-style prisons. Similarly, although Pitt sought means to relieve a seemingly relentless pressure on the gallows, he was no open advocate of the outright abolition of capital punishment. In the spring of 1787, between the failure of the Felons Anatomy Bill and the issuing of the Proclamation, one member of parliament moved the creation of a commission to comprehensively review the criminal law with the aim of reducing its all too obviously "bloody spirit." Pitt himself firmly rejected the motion, pleading not only the lack of time left in the present session (a perhaps irrelevant consideration, as parliamentary commissions extended across the life of more than one session), but also - as any seeming friend to a policy of maximum severity might do- that "it would be extremely dangerous to take any step which might have the smallest tendency to discredit the present existing system, before proper data and principles should be established whereon to found another." His further insistence, that no extensive revision of the criminal law could or should be undertaken without first being "fully weighed and settled by those learned and able men who filled" the judicial bench, clearly echoed Lord Chief Justice Loughborough's sentiments in rejecting the Felons Anatomy Bill the year before. ${ }^{142}$

Pitt might be willing to sponsor new measures and new institutions that might reduce the need to enforce the capital code with unrelenting stringency, but he did not share (at least not openly) the conviction of men of the next generation, such as Sir Samuel Romilly and Sir James Mackintosh, that the letter of the criminal law itself should be changed. Wilberforce himself claimed otherwise twenty years later, during one of his few symbolic interventions in parliament on behalf of Romilly and Mackintosh's campaign. On that later occasion, Wilberforce would claim that, "at an early period of his life, [Pitt] had intended to have a digest made of the whole of our criminal code, with a view of lessening, in a great degree, the number of capital punishments it contained ...". ${ }^{143}$ If

142. Cobbett, Parliamentary History 26 (1786-88): 1056-59; Hay, "Hanging and the English Judges," 148.

143. T.C. Hansard, ed., The Parliamentary Debates, from the Year 1803 to the Present Time, First Series, 41 vols. (London: R. Bagshaw et al., 1803-20), XI:400-401; he said much the same thing again two years later (XVI: 774). 
Pitt had ever privately said as much to Wilberforce at an earlier time, he either lied about his real intentions or he soon changed his mind in the face of strong opposition to "lessening" the extent of "the Bloody Code." Or perhaps the aging Wilberforce was simply being disingenuous, attempting to attach the immense posthumous prestige of the nation's now "martyred" war leader to a campaign that Pitt would never have supported in the $1780 \mathrm{~s} .{ }^{144}$

As for the young Wilberforce, however, we need not abandon our conception of him as an emerging champion of humanitarian causes, nor need we join John Pollock and Leon Radzinowicz in regarding him as an "inexperienced" or "immature" one. Both the Anatomy Bill and the Proclamation Society aimed to serve other "humane" purposes beyond simply preserving the lives of a larger proportion of condemned criminals in the mid-1780s. The Anatomy Bill was also meant to supply an educational need which, within the medical profession at least, was felt as urgently as were the claims of criminal justice. The Proclamation Society, beyond aiming to reduce the need for the gallows, was also powerfully expressive of the increasingly strongly felt moral imperatives of emergent middle-class and evangelical cultures. For the Society's principal adherents, those moral imperatives were probably far more compelling than were the more narrowly defined hopes of a culturally conservative government to find the means by which to reduce critical public scrutiny of capital punishment. This study has called attention to the complexity and multiple purposes of these two measures, a complexity that becomes particularly apparent in contrast with the conventional image of this era as one of growing humanitarian aspirations. It has sought to deepen our grasp of one past society, in all its richness and seeming contradictions. A similar appreciation of the multiple purposes, both congruent and conflicting, underlying criminal justice measures in our own age, might help to make us betterinformed citizens and critics of our own.

144. For the hagiographic treatment of Pitt during the years immediately following his death in 1806, see James J. Sack, "The Memory of Burke and the Memory of Pitt: English Conservatism Confronts Its Past, 1806-1829," Historical Journal 30 (1987): 623-40. 